\title{
Artificial biocrust establishment on materials of potash tailings piles along a salinity gradient
}

\author{
V. Sommer ${ }^{1,2} \cdot$ A. Palm ${ }^{2} \cdot$ A. Schink ${ }^{1} \cdot$ P. Leinweber ${ }^{3} \cdot$ N. Gose $^{2} \cdot$ U. Karsten ${ }^{1}$ (I) $\cdot$ K. Glaser $^{1}$
}

Received: 10 June 2021 / Revised: 14 September 2021 / Accepted: 14 September 2021 / Published online: 13 October 2021

(C) The Author(s) 2021

\begin{abstract}
Biocrust communities provide a pallet of ecosystem services, such as soil stabilization, altering of hydrological cycles and primary production, and often are the first colonizers of unvegetated surfaces during succession. Therefore, artificially establishing biocrusts can improve soil properties, for example, by stabilizing bare soil surfaces against erosion or by accumulating nutrients. In this study, the establishment of artificial biocrusts was tested for the restoration of potash tailings piles that result from potash fertilizer production and mostly consist of $\mathrm{NaCl}$. A biocrust cover as primary vegetation could decrease the saline seepage waters by trapping rainwaters, thereby reducing the environmental pollution. In a laboratory experiment, we created a salt gradient by mixing the tailings materials with non-saline dune sand. Surface material of the abandoned potash tailings pile Neuhof-Ellers (NE) and material of the Infiltration Hampering Stratum (IHS) were tested, along with a treatment with bone char ${ }^{\text {plus }}\left(\mathrm{BC}^{\text {plus}}\right)$ and sodium alginate. A mixture of $50 \%(\mathrm{w} / \mathrm{w})$ IHS and dune sand was most successful for the establishment of green biocrust microalgae, based on increased biomass and photosynthetic performance. The chlorophyll $a$ content was negatively correlated with the electrical conductivity (EC), and was significantly increased in the $\mathrm{BC}^{\text {plus }}$ and sodium alginate treatment, while biocrusts failed to establish on pure tailings piles substrates. The limit of the substrates EC for biocrust establishment was $35 \mathrm{mS} \mathrm{cm}^{-1}$. This limit provides a baseline for future studies that should use $\mathrm{BC}^{\text {plus }}$ and sodium alginate to increase the success of biocrust establishment on potash tailings piles.
\end{abstract}

Keywords Biocrust $\cdot$ Restoration $\cdot$ Potash industry $\cdot$ Inoculation $\cdot$ Green algae

\section{Introduction}

Biological soil crusts (biocrusts) are often overlooked, but ecologically significant communities found at the soilatmosphere interface. A biocrust is defined as an association of various micro- and macro-organisms that inhabit the uppermost millimeters of the soil. Filamentous cyanobacteria and green algae interweave the soil surface and excrete sticky extracellular polymeric substances (EPS) that bind soil particles to each other and to the organisms (Rossi et al. 2017). Together with unicellular microalgae, for example,

U. Karsten

ulf.karsten@uni-rostock.de

1 Applied Ecology and Phycology, University of Rostock, Albert-Einstein-Str. 3, 18059 Rostock, Germany

2 Upi UmweltProjekt Ingenieursgesellschaft, Breite Straße 30, 39576 Stendal, Germany

3 Soil Sciences, University of Rostock, Justus-von-Liebig-Weg-6, 18059 Rostock, Germany green algae and diatoms, as well as other bacteria, archaea, and sometimes also mosses and lichens, a robust biocrust is formed.

Biocrusts dominate drylands worldwide, creating biodiversity hotspots (Weber et al. 2016a, b), but are also found in other biomes. In newly emerging habitats, such as glacier forefields, biocrusts are one of the first colonizers (Breen and Lévesque 2006; Baumann et al. 2017).

Biocrust communities provide a range of ecological services. As soil stabilizing surfaces, biocrusts reduce erosion by wind and water (Belnap and Büdel 2016), and their important role in hydrological processes has been discussed in various studies (Belnap 2006; Bowker et al. 2013; Chamizo et al. 2016; Gypser et al. 2016; Kidron 2016, 2019; Whitney et al. 2017; Rodríguez-Caballero et al. 2018). In their mostly harsh habitats, biocrust plays an important role in nitrogen (Barger et al. 2016) as well as carbon cycles (Sancho et al. 2017), thereby accounting for $7 \%$ of the global terrestrial net primary production and about $50 \%$ of terrestrial biological $\mathrm{N}$ fixation (Elbert et al. 2012). Despite their adaption to harsh 
environmental conditions, biocrusts should be regarded as vulnerable communities worthy of protection. They are strongly affected by disturbances such as trampling and grazing by cattle (Belnap and Eldridge 2003; Yang et al. 2020), vehicle traffic (Zaady et al. 2013), and mining activities (Williams et al. 2019). A recent study reported the negative effect of biocrust disturbance on soil $\mathrm{CO}_{2}$ emission (Yang et al. 2020). To prevent the loss of that valuable vegetation cover, several studies aimed at the rehabilitation of biocrusts. As an example, fencing is a passive method to exclude herbivory and trampling (Condon et al. 2020). However, the natural recovery of disturbed biocrusts in water-limited drylands is rather slow (Belnap and Eldridge 2003), and the time for recovery strongly depends on several parameters, such as environmental conditions (e.g., water availability) or timing of the disturbance (Weber et al. 2016a, b).

Therefore, active intervention may be required for faster re-establishment of a viable and dense biocrust cover. This was realized in studies that directly applied representative biocrust organisms to the soil surface, using cyanobacteria (Chen et al. 2006; Rossi et al. 2017; Fattahi et al. 2020; Zhao et al. 2021), bryophytes (Xiao et al. 2015; Bu et al. 2018; Cruz de Carvalho et al. 2018), or lichens (Ballesteros et al. 2017). Furthermore, the application of stabilizers (Park et al. 2017; Peng et al. 2017; Li et al. 2021) showed accelerated development of cyanobacterial biocrusts.

Besides the restoration of disturbed biocrusts, artificial biocrust development can be actively initiated in areas without previous natural biocrust cover, in order to prevent or reverse soil degradation (Chen et al. 2006; Rossi et al. 2017; Chi et al. 2020; Li et al. 2021) or to stabilize sand and other surfaces, such as artificial water-body margins (Cruz de Carvalho et al. 2018). So far, research on artificial biocrusts is restricted to dryland areas, while such studies are absent from Central Europe.

Degraded landscapes in Europe emerged, for example, following potash mining. During potash fertilizer production, vast amounts of waste salt material (mostly $\mathrm{NaCl}$ ) need to be deposited in so-called potash tailings piles. In central Germany, potash tailings piles shape the landscape due to their large scales with heights of up to $200 \mathrm{~m}$, and due to the impact of salt on the surrounding environment. Rainfall washes out saturated salt brines and thus creates extremely saline conditions in habitats far from the coast. Several studies evaluated covering potash tailings piles with higher plants, in order to trap rainwater and reduce the salt output (Schmeisky and Podlacha 2000; Niessing 2005). However, these methods require large amounts of non-saline substrates, which is difficult to apply to the steep slopes of larger potash tailings piles. A recent approach used insoluble additives mixed to a small percentage with the salt waste (Kockx 2017). This created an Infiltration Hampering Stratum (IHS) that increased the surface evaporation by
$50 \%$, thereby decreasing the leakage of saturated salt brine (Kockx 2017). Moreover, in a pilot field study, a spontaneous settlement of young biocrusts was recorded from the IHS (Sommer et al. 2019). Therefore, the application of biocrusts moved into focus as a potential biotool for the surface restoration of potash tailings piles. A biocrust cover could potentially decrease the amount of saline seepage water by trapping rainwater, and increasing water retention as well as evaporation, and in this way lower the salt impact of potash tailings piles on the environment. Biocrusts have recently been studied in the surrounding of several tailings piles in Germany, and numerous green algal strains have been isolated, established as clonal cultures, and identified for further experiments (Sommer et al. 2020a, b). These isolates are promising candidates for artificial biocrust formation since they are expected to tolerate saline conditions.

Salt-tolerant microalgae are able to survive saline conditions to a certain level. EPS contribute to salinity tolerance since these compounds also act as an extracellular barrier to reduce the salt impact (Chen et al. 2006). Furthermore, the intracellular production and accumulation of salt-protective organic osmolytes has been characterized in several terrestrial green algae (Gustavs et al. 2010, 2011). These osmotically active substances increase intracellular osmotic pressure to withstand extracellular osmotic pressure caused by salt ions. However, the production of organic osmolytes requires energy and thus is metabolically costly (Erdmann and Hagemann 2001). At high extracellular salinity level, a tipping point of the osmotic balance may be reached, with water flowing out of the cell due to the rising osmotic gradient, leading to shrinkage and, eventually, to physical damage.

Therefore, knowledge of the upper limits of substrate salinity for biocrust algae is important for the establishment of biocrusts on potash tailings piles. The inoculated algal cells have to (1) survive the inoculation on the saline substrate, and (2) be able to accumulate biomass over a longer period of cultivation. Consequently, the substrate salinity should not induce instant cell death, but should allow the cells to survive over time and, importantly, grow. The aim of the present study was to assess the establishment of artificial biocrusts by inoculating selected green algae on potash tailings piles materials along a salinity gradient. The results should provide information on the limit for both, short-term inoculum survival and long-term biomass accumulation.

In addition, the usage of a stabilizer (sodium alginate) as well as a fertilizer (bone char ${ }^{\text {plus }}, \mathrm{BC}^{\text {plus }}$ ) to enhance biocrust establishment was evaluated. Sodium alginate had been proven to increase biocrust establishment (Peng et al. 2017). Bone char as a recycling product is made by pyrolysis of animal bones from slaughterhouse waste. Because bone char is rich in $\mathrm{P}$, it is discussed as a promising alternative P-fertilizer for sustainable agriculture (Siebers and 
Leinweber 2009). Furthermore, bone char has been enriched with sulfur, the result being BC $^{\text {plus }}$ (Zimmer et al. 2019). $\mathrm{BC}^{\text {plus }}$ application in a pot experiment with rye grass showed a yield comparable to a common P-fertilizer application, whereas conventional bone char did not reach that level (Zimmer et al. 2019). Therefore, providing $\mathrm{BC}^{\text {plus }}$ as a $\mathrm{P}$ source for artificial green algal biocrusts could increase their biomass and thus support the establishment of biocrusts.

\section{Material and methods}

\section{Green algal strains}

Three green algal strains (Supplementary Fig. 1) that were isolated from biocrusts in the surrounding of potash tailings piles were used for inoculation: Pseudostichococcus monallantoides WT-3-1-H (MT991551; Sommer et al. 2020b), Chloroidium sp. SY-1-2-R, and Nannochloris sp. TTF-3-1-J, which were identified based on 18S rRNA sequencing. These strains were isolated using saline medium (agarized, 3\% (w/v) $\mathrm{NaCl}$ ); the details on the isolation as well as habitat descriptions have been published earlier (Sommer et al. 2020a, b). Pre-cultures were maintained separately in aerated Erlenmeyer flasks filled with $3 \mathrm{~N}-\mathrm{BBM}+\mathrm{V}$ medium (Bischoff and Bold 1963; modified by Starr and Zeiskus 1993) that was enriched with $6 \%(\mathrm{w} / \mathrm{v})$ $\mathrm{NaCl}$. Culturing was approximately for 8 weeks, until sufficient amounts of biomass for inoculation were obtained. All cultures were kept at $20^{\circ} \mathrm{C}$ in a $16: 8 \mathrm{~h}$ light:dark cycle (Lumilux daylight L36W/954, Osram, 80,807 Munich, Germany) with $30 \mu \mathrm{mol}$ photons $\mathrm{m}^{-2} \mathrm{~s}^{-1}$.

\section{Description of the saline and non-saline materials}

Four types of saline materials were used for the experiment: two potash tailings piles materials and two salt materials. Surface material (uppermost $5 \mathrm{~cm}$ ) of the Infiltration Hampering Stratum (IHS) was collected from residuals of a pilot study on a small-scale potash tailings pile model (Kockx 2017; Sommer et al. 2019). In addition, surface material derived from the plateau area of the abandoned potash tailings pile in Neuhof-Ellers (NE), Germany, was collected in 2018. The pure waste salt (WS), i.e., the overburden representing the solid, fresh tailings from the potash industry, was collected in April 2016. In addition, sodium chloride $(\mathrm{NaCl})$ was used. Moreover, non-saline dune sand was collected in March 2018 from the Baltic Sea coast, Warnemünde beach, Rostock, Germany. All the mentioned substrates were airdried and sieved ( $<2 \mathrm{~mm}$ ) prior to utilization, whereas WS was additionally dried in the oven $\left(70{ }^{\circ} \mathrm{C}\right.$, overnight $)$ before sieving.

\section{Preparation and characterization of the salt gradient and the treatments}

The saline materials IHS, IES, WS, and $\mathrm{NaCl}$ were partly mixed with non-saline dune sand (Table 1) in order to create a salinity gradient. The $25 \%$ (w/w) IHS substrate, for example, was prepared by mixing $25 \mathrm{~g}$ of the IHS material with $75 \mathrm{~g}$ dune sand. The substrates $2.5 \%$ (w/w) $\mathrm{NaCl}$ and NoSalt $(100 \%(w / w)$ dune sand) were used in addition. The additive treatment $\left(\mathrm{A}^{+}\right)$was prepared for each substrate by adding $1 \%(\mathrm{w} / \mathrm{w})$ sulfur-enriched bone char (1-2 mm, BC ${ }^{\text {plus }}$, Burgstaller et al 2012, Zimmer et al. 2019). The treatment without additive $\left(\mathrm{A}^{-}\right)$received no $\mathrm{BC}^{\text {plus }}$. Figure 1 provides an overview over all substrates and the two treatments.

The electrical conductivity (EC) and the $\mathrm{pH}$ of the substrates were measured before the experiment. Ten grams of substrate was mixed with $50 \mathrm{~mL}$ distilled water $(\mathrm{EC}<5 \mu \mathrm{S}$ $\mathrm{cm}^{-1}$ ) to obtain a soil solution for the EC measurement. The samples were shaken for $1 \mathrm{~h}$. After $30 \mathrm{~min}$ of sedimentation, the EC was determined in the supernatant using a conductivity probe (Seven MultiTM, Mettler Toledo, in Lab 731 probe, Switzerland). The $\mathrm{pH}$ was measured as previously described (Sommer et al. 2020a).

The premixed substrates were added into 6-well plates $\left(9.6 \mathrm{~cm}^{2}\right.$ surface per well) that were perforated three times

Table 1 Overview over the substrates used for artificial biocrust formation. Saline materials were the potash tailings piles IHS (Infiltration Hampering Stratum), material from the potash tailings pile NE (Neuhof-Ellers), fresh potash tailings WS (waste salt), and $\mathrm{NaCl}$; NoSalt (non-saline dune sand)

\begin{tabular}{lll}
\hline Substrate & $\begin{array}{l}\text { Concentration of } \\
\text { saline material }[\% \\
(w / w)]\end{array}$ & $\begin{array}{l}\text { Concentration of non- } \\
\text { saline dune sand [\% } \\
(w / w)]\end{array}$ \\
\hline $25 \%(w / w) ~ I H S$ & 25 & 75 \\
$50 \%(w / w) ~ I H S$ & 50 & 50 \\
$75 \%(w / w) ~ I H S$ & 75 & 25 \\
$100 \%(w / w) ~ I H S$ & 100 & 0 \\
$25 \%(w / w) \mathrm{NE}$ & 25 & 75 \\
$50 \%(w / w) \mathrm{NE}$ & 50 & 50 \\
$75 \%(w / w) \mathrm{NE}$ & 75 & 25 \\
$100 \%(w / w) \mathrm{NE}$ & 100 & 0 \\
$1 \%(\mathrm{w} / \mathrm{w}) \mathrm{WS}$ & 1 & 99 \\
$5 \%(w / w) \mathrm{WS}$ & 5 & 95 \\
$10 \%(w / w) \mathrm{WS}$ & 10 & 90 \\
$15 \%(w / w) \mathrm{WS}$ & 15 & 85 \\
$1 \%(w / w) \mathrm{NaCl}$ & 1 & 99 \\
$2.5 \%(w / w) \mathrm{NaCl}$ & 2.5 & 97.5 \\
$5 \%(w / w) \mathrm{NaCl}$ & 5 & 95 \\
$10 \%(w / w) \mathrm{NaCl}$ & 10 & 90 \\
$15 \%(w / w) \mathrm{NaCl}$ & 15 & 85 \\
$\mathrm{NoSalt}$ & 0 & 100 \\
\hline
\end{tabular}


a
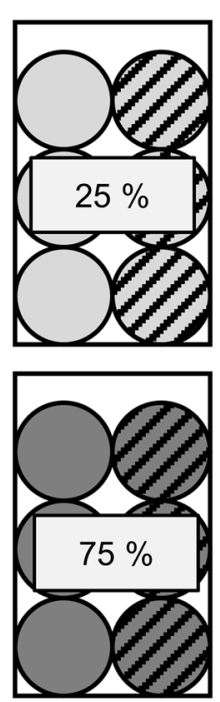

C
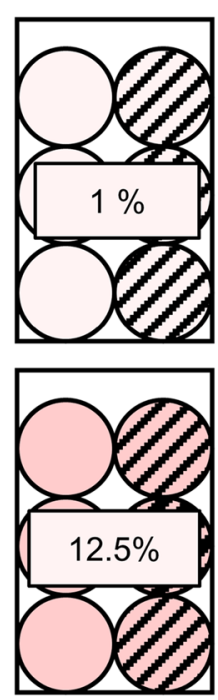
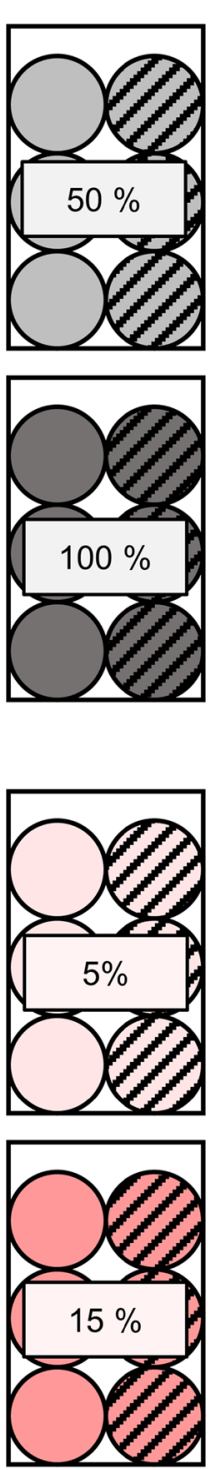

b
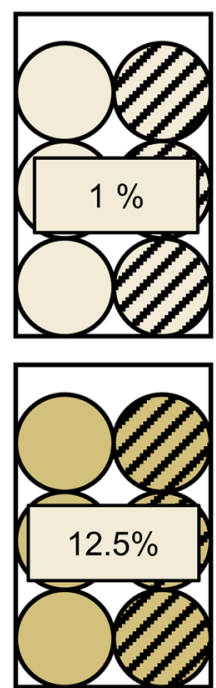

d
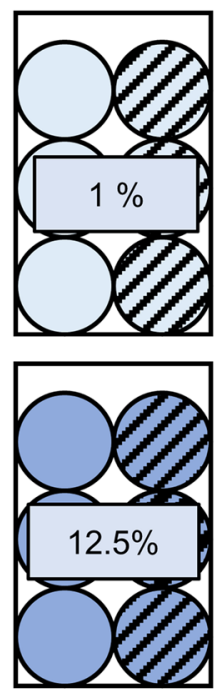

Fig. 1 Overview on the 6-well plates willed with the substrates used for artificial biocrust formation, including concentrations of added saline materials (w/w). a IHS (Infiltration Hampering Stratum); b

at the bottom; each well was filled $1 \mathrm{~cm}$ high. Three replicates without $\left(\mathrm{A}^{-}\right)$and three replicates with additive treatment $\left(\mathrm{A}^{+}\right)$were used for each substrate. In addition, the wells for the additive treatments were sprayed with a Na-Alginate solution using a sterile pump spray, resulting in $2 \mathrm{~g} \mathrm{~m}^{-2} \mathrm{Na}$-alginate (Peng et al. 2017). All plates were closed with transparent plastic lids and watered from the bottom using artificial rainwater (Williams et al. 2005) until the substrates reached saturation.
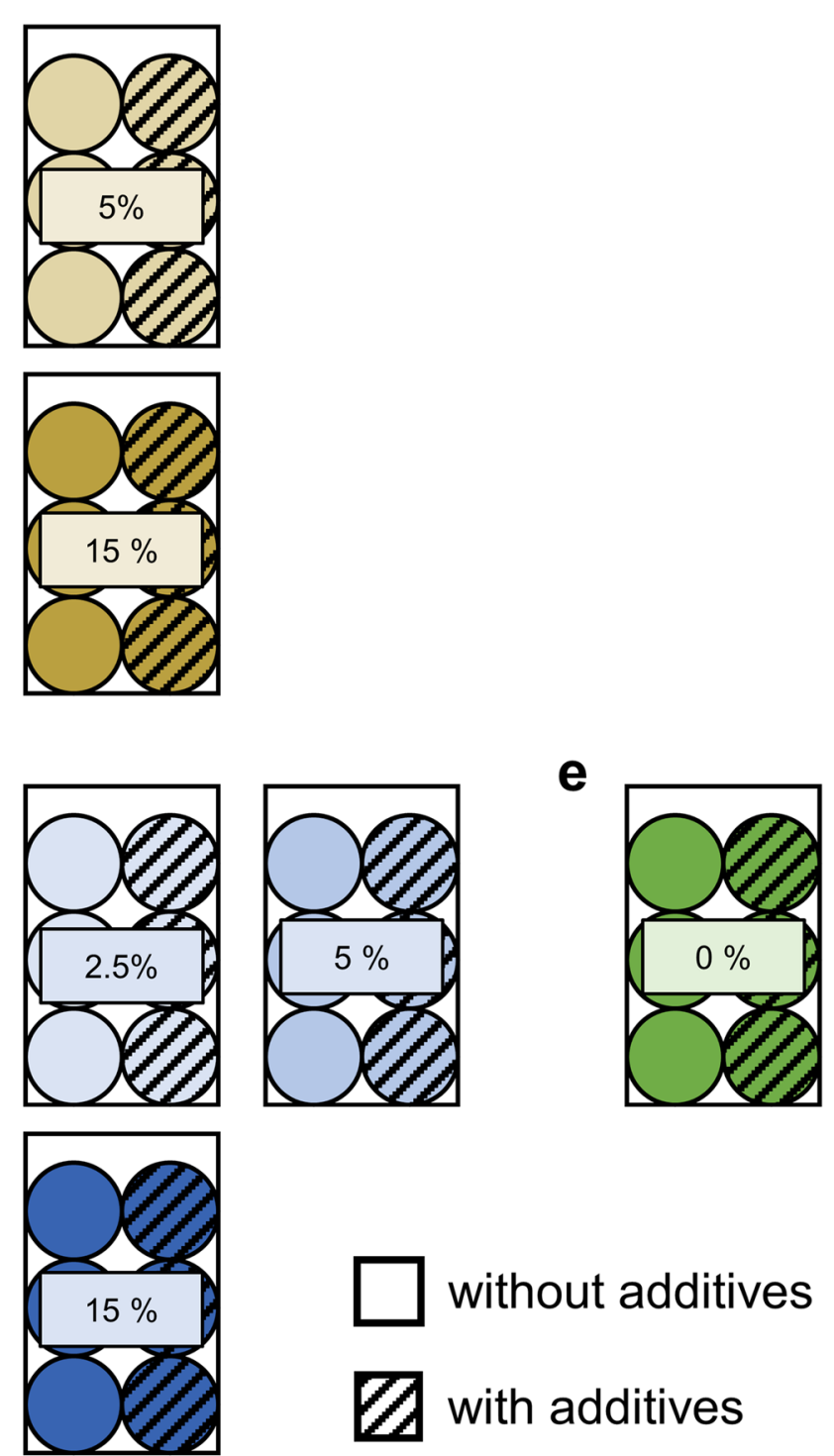

without additives

with additives

NE (Neuhof-Ellers); $\mathbf{c}$ WS (waste salt); d NaCl; e NoSalt (non-saline dune sand). Additives: $\mathrm{BC}^{\text {plus }}$ and sodium alginate

\section{Preparation and characterization of the inoculum}

The unialgal strains were harvested from culture medium using sterile glass pipettes, and afterwards carefully suspended using sterile syringes. The collected cells of the three individual strains were mixed afterwards in a small vessel. Microscopic examination of the mixed inoculation suspension was performed to ensure vitality of the cells and to roughly estimate the proportional percentage of each 
green algal strain in the mixture. Three microscope slides with one drop inoculation suspension each were evaluated to roughly estimate the proportion of the three strains, which was approximately 9:3:1 (Pseudostichococcus:Chloroidium :Nannochloris).

The average chlorophyll $a$ content $(\mathrm{Chl} a)$ of $4 \mathrm{~mL}$ inoculation suspension was measured in four replicates. The biomass was filtered with Whatman GF/6 glass fiber filters and was stored at $-20{ }^{\circ} \mathrm{C}$ until $\mathrm{Chl} a$ extraction. A pinch of $\mathrm{MgCO}_{3}$ was added to the samples, and Chl $a$ was extracted with $3 \mathrm{~mL} 96 \%$ ethanol in a water bath $\left(78^{\circ} \mathrm{C}, 5 \mathrm{~min}\right)$. After centrifugation $(4.640 \times g, 5 \mathrm{~min})$, the absorbance was measured in $1 \mathrm{~cm}$ cuvettes at 750 and $665 \mathrm{~nm}$. The Chl $a$ content of the inoculum was calculated (HELCOM 2015; LUNG SOP-Nr: 640-Chlorophyll-KG):

$\mu g$ Chla $^{-1}=\frac{\left(E_{665-} E_{750}\right) * v * 10^{6}}{83 * V * d}$

where $v=$ extraction volume $[\mathrm{mL}], V=$ filtered volume [mL], and $d=$ length of cuvette.

The average dry mass (DM) of $4 \mathrm{~mL}$ inoculation suspension was determined by filtration of four replicates. Pre-weighed Whatman GF/6 glass fiber filters with the attached biomass were dried in the oven overnight $\left(40{ }^{\circ} \mathrm{C}\right)$ and weighted subsequently. The DM was calculated by subtracting the empty weight of the respective filter from the filter with attached dried biomass.

\section{Inoculation and experimental set-up}

The inoculation suspension was transferred to sterile pump spray bottles, and $450 \mu \mathrm{L}$ (DM $405 \pm 19 \mathrm{mg} \mathrm{m}^{-2}$; Chl $a$ $1.46 \pm 0.11 \mathrm{mg} \mathrm{m}^{-2}$ ) was equally sprayed on the substrate surface of each well from approximately $5 \mathrm{~cm}$ distance. The lids were closed but the plates remained unsealed in order to provide constant gas exchange. Each 6-well plate was placed in a plastic coaster and transferred to mini indoor greenhouses $(36 \times 22 \times 13 \mathrm{~cm}$; Pflanzen-Kölle, Germany). The cultivation was set at $20^{\circ} \mathrm{C}$ and $25-30 \mu \mathrm{mol}$ photons $\mathrm{m}^{-2} \mathrm{~s}^{-1}$ (16:8 h light:dark cycles; Lumilux daylight L36W/954, Osram, Germany) reaching the sample surface. The samples were kept constantly moistened by adding artificial rainwater to the empty spaces between the wells, providing saturated air humidity in addition to the watering from the bottom before the experiment. The artificial rainwater was refilled once a week. The experiment was run for 4 weeks.

\section{Biocrust monitoring during the experiment}

During the experimental phase, the biocrusts were inspected every week. Photographs were taken from each 6-well plate, and imaging PAM (pulse amplitude modulation, I-PAM) measurements were performed for each well using an imaging PAM IMAG-CG/S equipped with an IMAG-MIN/B measuring head (blue light) and an IMAG-K-6 camera (G-145B, Heinz Walz GmbH, Germany). The effective quantum yield of the photosystem II (PSII), in short Y(II), was measured in the center of each well. The measuring area $(24 \mathrm{~mm} \times 32 \mathrm{~mm})$ corresponded to $81.7 \%$ of the well surface.

\section{Measurement of $\mathrm{Chl} a$ and water content}

After the experimental phase, the surface (i.e., the uppermost $3 \mathrm{~mm}$ ) of each well was collected for the determination of Chl $a$. The Chl $a$ extraction was performed as described above. The absorbance of the extract was measured in $1 \mathrm{~cm}$ cuvettes at 750, 696, 665, 649, and $632 \mathrm{~nm}$. The Chl $a$ content $\left[\mathrm{mg} \mathrm{m}^{-2}\right]$ was calculated as described by Ritchie (2008) and normalized to area.

The water content of the remaining sub-crust substrate was determined as follows: The mass of the substrate was recorded immediately after removing the surface for the $\mathrm{Chl}$ $a$ measurements. Samples were then dried overnight at $70{ }^{\circ} \mathrm{C}$ and subsequently cooled in a desiccator, followed by DM measurement. The water content $(\mathrm{w} / \mathrm{w})$ was calculated by subtracting the DM from the fresh mass.

\section{Microscopic examination}

In order to monitor any changes in microalgal composition, the biocrusts were studied under an Olympus BX51 light microscope after 4 weeks using differential interference contrast and $400 \times$ magnification (DIC; Olympus, Germany). For this, a small amount of the biocrust (e.g., biocrusts attached to a few sand grains) from each well was carefully collected, aiming at minimal disturbance of the biocrust. The microalgal composition was assessed by estimating the proportions of the three green algal strains.

\section{Statistical analyses}

The correlation between the determined properties $(\mathrm{pH}$, $\mathrm{EC}, \mathrm{Chl} a$, and $\mathrm{Y}(\mathrm{II})$ ) at week four was calculated using the Spearman's rank correlation test and displayed as a correlation matrix. The Wilcoxon rank sum test was performed to evaluate significant differences between the measured variables in the two treatments $\left(\mathrm{A}^{-}, \mathrm{A}^{+}\right)$. Statistical analyses were computed with $\mathrm{R}$ (V 3.6.3) in the $\mathrm{R}$ studio interface (V. 1.2.5033, RStudio Inc.). In order to identify the maximum EC suitable for biocrust establishment, the substrates EC that allowed successfully established biocrusts $\left(\mathrm{EC}_{\mathrm{BSC} \_ \text {growth }}\right)$ was subset from the mean $\mathrm{EC}$ of the respective substrate. The $\mathrm{EC}_{\mathrm{BSC}}$ growth was defined as the $\mathrm{EC}$ only of samples with Chl $a_{\text {End }}>\operatorname{Chl} a_{\text {inoculum }}$ (Chl $a_{\text {End }}$ : Chl $a$ 
content after the experiment; $\mathrm{Chl} a_{\text {inoculum }}$ : Chl $a$ content of the inoculum).

\section{Results}

\section{Characteristics of the substrates}

The EC of the substrate-water solution was between 0.04 and $62 \mathrm{mS} \mathrm{cm}^{-1}$ (Table 2). Comparing the EC of the non-mixed materials (100\%), IHS had a higher EC than NE, whereas the NoSalt (dune sand) had the lowest EC. WS and $\mathrm{NaCl}$ had similar ECs. The substrates treated with $\mathrm{BC}^{\text {plus }}$ had slightly higher ECs than the samples without the additive.

The $\mathrm{pH}$ of the substrates ranged between 6.7 and 8.8. The majority of the samples was neutral $(8>\mathrm{pH}>6.5)$, whereas a few samples without added $\mathrm{BC}^{\text {plus }}(100 \%(\mathrm{w} / \mathrm{w})$ IHS, $5-15 \%(\mathrm{w} / \mathrm{w}) \mathrm{NaCl})$ were basic $(\mathrm{pH}>8)$. The lowest $\mathrm{pH}$ was measured in WS as well as in the NoSalt samples. Overall, the $\mathrm{pH}$ was significantly lower with added $\mathrm{BC}^{\text {plus }}$ (Table 3 ).

\section{Development of the induced biocrusts observed by visual inspection}

Directly after inoculation at the beginning of the experiment, biocrusts were undetectable. However, over the course of 4 weeks, visible biocrusts developed on several substrates
Table 3 Wilcoxon rank sum test results to test for significant differences in the respective treatments (without additives, with additives). The $\mathrm{pH}$ and EC of the premixed substrates were measured before the experiment, Y(II) was measured during the experiment, and $\mathrm{Chl} a$ and the water content were measured after 4 weeks. Significant $p$-values are marked with asterisks $(*)$ variables between the two

\begin{tabular}{lll}
\hline & w & $p$ \\
\hline pH & 1821 & $0.026^{*}$ \\
EC & 1341 & 0.474 \\
Y(II) week 0 & 1491.5 & 0.837 \\
Y(II) week 1 & 1362 & 0.519 \\
Y(II) week 2 & 1371.5 & 0.564 \\
Y(II) week 3 & 1398 & 0.679 \\
Y(II) week 4 & 1362 & 0.512 \\
Chl $a$ content & 1883 & $0.009^{*}$ \\
Water content & 1084 & 0.152 \\
\hline
\end{tabular}

(Fig. 2), recognizable by the appearance and subsequent deepening of green color.

On the IHS substrate, a green surface was recorded in one replicate of $25 \%(\mathrm{w} / \mathrm{w})$ IHS $\mathrm{A}^{+}$after 4 weeks, and in three replicates of $50 \%(\mathrm{w} / \mathrm{w})$ IHS $\mathrm{A}^{-}$. Due to the dark coloring of the NE materials, only a slightly green cover was detectable, namely on three replicates of $25 \%(\mathrm{w} / \mathrm{w}) \mathrm{NE} \mathrm{A}^{+}$. The biocrusts on WS and $\mathrm{NaCl}$ were most prominent on all $1 \%$ $(\mathrm{w} / \mathrm{w}) \mathrm{A}^{+}$replicates, whereas the three $1 \%(\mathrm{w} / \mathrm{w}) \mathrm{A}^{-}$replicates showed a slightly less greenish surface. One replicate of $2.5 \%(\mathrm{w} / \mathrm{w}) \mathrm{NaCl} \mathrm{A}{ }^{+}$showed a visibly green cover.

Several biocrusts completely covered the substrates surfaces, whereas some replicates of the IES and NE substrates had less evenly distributed algal covers. These replicates showed either an accumulation on the edges of the wells
Table 2 Characteristics of the substrates used for artificial biocrust establishment. The percentages refer to $(\mathrm{w} / \mathrm{w})$ of the saline materials mixed with non-saline dune sand: IHS (Infiltration Hampering Stratum), NE (Neuhof-Ellers), WS (waste salt), and $\mathrm{NaCl}$. The treatment $\mathrm{A}^{-}$was without additives and $\mathrm{A}^{+}$with additive (BC $\left.{ }^{\text {plus }}\right)$

\begin{tabular}{|c|c|c|c|c|c|c|c|c|}
\hline \multirow[t]{3}{*}{ Substrate } & \multicolumn{4}{|c|}{$\mathrm{EC}\left[\mathrm{ms} \mathrm{cm}^{-1}\right]$} & \multicolumn{4}{|l|}{$\mathrm{pH}$} \\
\hline & \multicolumn{2}{|l|}{$\mathrm{A}^{-}$} & \multicolumn{2}{|l|}{$\mathrm{A}^{+}$} & \multicolumn{2}{|l|}{$\mathrm{A}^{-}$} & \multicolumn{2}{|l|}{$\mathrm{A}^{+}$} \\
\hline & Mean & SD & Mean & SD & Mean & SD & Mean & SD \\
\hline $25 \%(w / w)$ IHS & 18.443 & 0.597 & 17.520 & 1.394 & 7.556 & 0.007 & 7.521 & 0.080 \\
\hline $50 \%(w / w)$ IHS & 33.167 & 2.346 & 35.067 & 0.899 & 7.533 & 0.159 & 7.476 & 0.243 \\
\hline $75 \%(w / w)$ IHS & 43.133 & 0.450 & 48.967 & 1.053 & 7.852 & 0.120 & 7.606 & 0.233 \\
\hline $100 \%(w / w)$ IHS & 54.033 & 5.792 & 62.067 & 0.125 & 8.051 & 0.069 & 7.517 & 0.048 \\
\hline $25 \%(w / w) \mathrm{NE}$ & 8.510 & 0.757 & 9.433 & 0.249 & 7.657 & 0.030 & 7.798 & 0.033 \\
\hline $50 \%(w / w) \mathrm{NE}$ & 16.177 & 0.313 & 16.294 & 1.019 & 7.768 & 0.022 & 7.855 & 0.038 \\
\hline $75 \%(w / w) \mathrm{NE}$ & 22.767 & 0.330 & 24.733 & 0.450 & 7.884 & 0.102 & 7.855 & 0.058 \\
\hline $100 \%(w / w)$ NE & 28.167 & 0.047 & 29.433 & 0.478 & 7.758 & 0.036 & 7.832 & 0.503 \\
\hline $1 \%(\mathrm{w} / \mathrm{w}) \mathrm{WS}$ & 2.890 & 0.659 & 4.300 & 1.126 & 6.744 & 0.023 & 6.797 & 0.035 \\
\hline $5 \%(\mathrm{w} / \mathrm{w}) \mathrm{WS}$ & 11.860 & 0.991 & 14.917 & 2.208 & 6.915 & 0.035 & 6.746 & 0.070 \\
\hline $10 \%(\mathrm{w} / \mathrm{w}) \mathrm{WS}$ & 34.300 & 2.707 & 35.600 & 2.142 & 6.970 & 0.035 & 7.088 & 0.033 \\
\hline $15 \%(w / w) W S$ & 42.200 & 4.825 & 48.267 & 4.969 & 7.004 & 0.021 & 7.154 & 0.166 \\
\hline $1 \%(\mathrm{w} / \mathrm{w}) \mathrm{NaCl}$ & 3.817 & 0.126 & 4.200 & 0.259 & 7.549 & 0.023 & 7.331 & 0.330 \\
\hline $2.5 \%(\mathrm{w} / \mathrm{w}) \mathrm{NaCl}$ & 8.840 & 0.313 & 9.720 & 0.306 & 7.009 & 0.173 & 6.947 & 0.337 \\
\hline $5 \%(\mathrm{w} / \mathrm{w}) \mathrm{NaCl}$ & 12.433 & 0.192 & 22.467 & 1.470 & 8.072 & 0.022 & 7.609 & 0.300 \\
\hline $10 \%(w / w) \mathrm{NaCl}$ & 32.967 & 0.806 & 34.400 & 1.023 & 8.315 & 0.081 & 7.592 & 0.435 \\
\hline $15 \%(w / w) \mathrm{NaCl}$ & 48.300 & 0.216 & 47.300 & 1.417 & 8.445 & 0.014 & 7.665 & 0.395 \\
\hline NoSalt & 0.041 & 0.000 & 0.141 & 0.012 & 7.869 & 0.066 & 7.444 & 0.070 \\
\hline
\end{tabular}




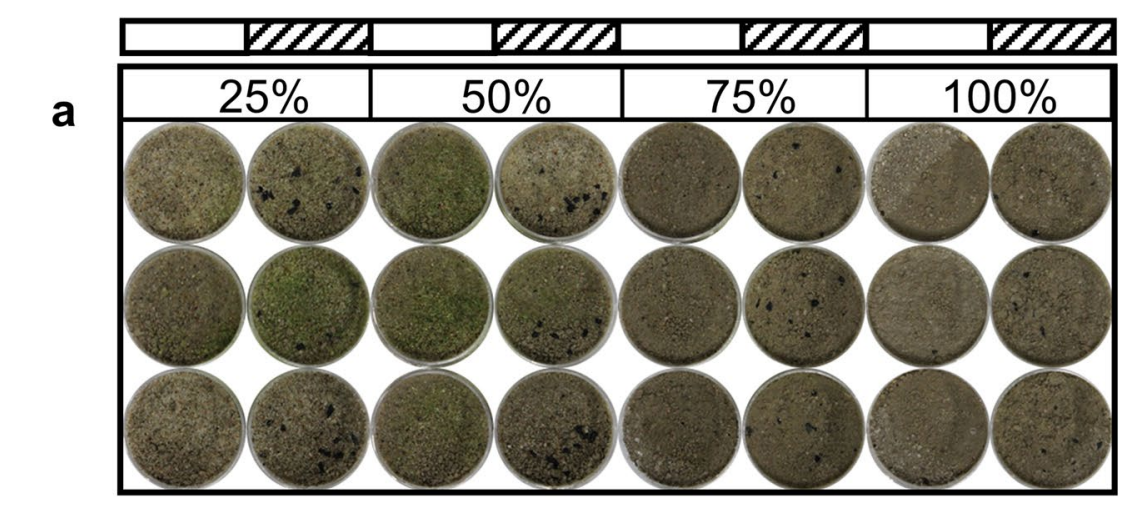

b

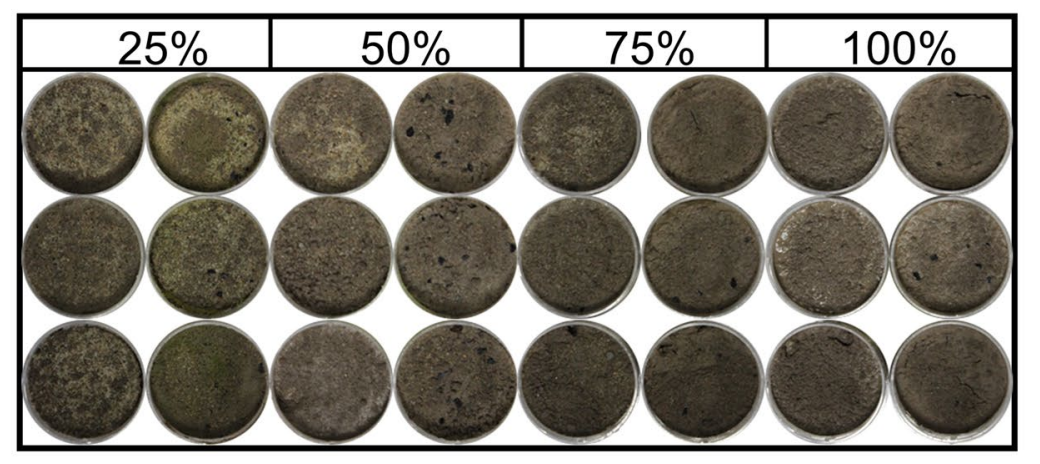

C

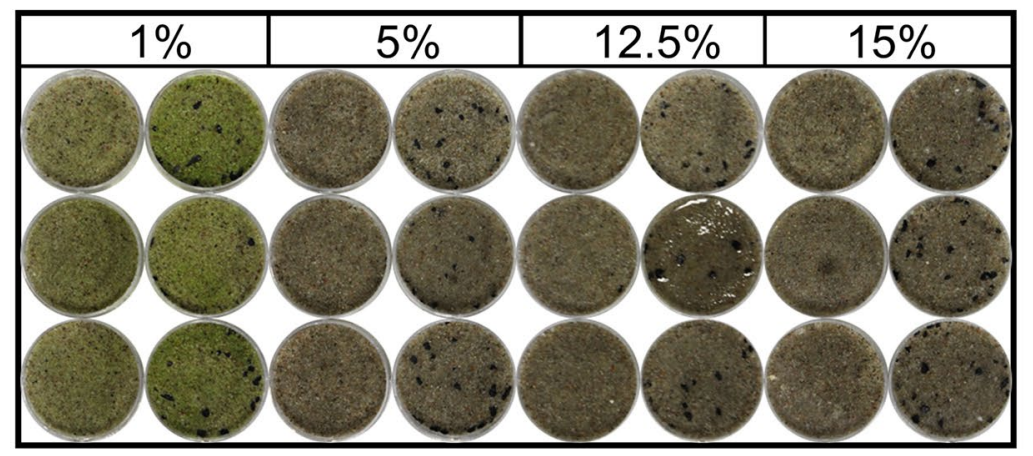

d

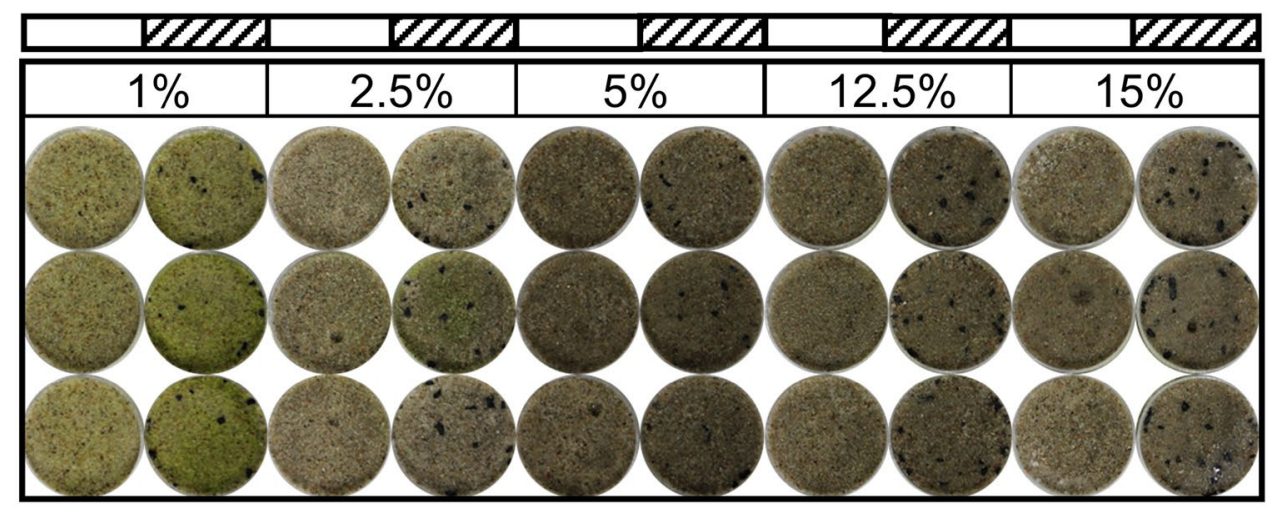

$\square$ without additives e

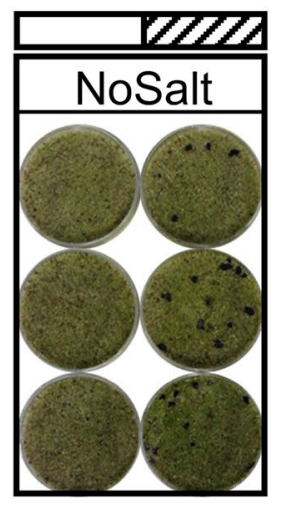

$\square$

with additives
Fig. 2 Photographs of the 6-well plates filled with saline substrates 4 weeks after inoculation with a green algal mixture, including the percentages $(w / w)$ of saline materials mixed with non-saline dune sand: a IHS (Infiltration Hampering Stratum); b NE (Neuhof-Ellers); c WS (waste salt); d NaCl; e NoSalt (100\% dune sand); additives: $\mathrm{BC}^{\text {plus }}$ and sodium alginate 
$\left(25 \%\right.$ (w/w) $\mathrm{NE} \mathrm{A}^{+}$, Fig. 2b) or a slightly uneven coverage at the surface (25\% and 50\% (w/w) IHS, Fig. 2a).

\section{Microscopic observation of the induced biocrusts}

The biocrusts were inspected under the microscope after 4 weeks. The dominant microalga was Pseudostichococcus monallantoides that formed filaments interweaving the substrate particles, which easily disintegrated during handling under the microscope. The other two green algae used for inoculation, Chloroidium sp. and Nannochloris sp., were much less present. The proportion was estimated to be
50:5:1 (Pseudostichococcus:Chloroidium:Nannochloris). There was no specific pattern of the biocrust community found among the substrates regarding both material type and salinity. The cells of $P$. monallantoides appeared to be the most vital, showing intact cell components with evenly green chloroplasts. In contrast, some cells of Chloroidium sp. exhibited irregular shapes, instead of the elliptical cells typical for the genus (Supplementary Fig. 1). Furthermore, chloroplasts in cells of Chloroidium sp. and Nannochloris sp. were also often irregularly shaped and pale green, while cells appeared to accumulate intracellular grains/droplets (probably starch/lipids).

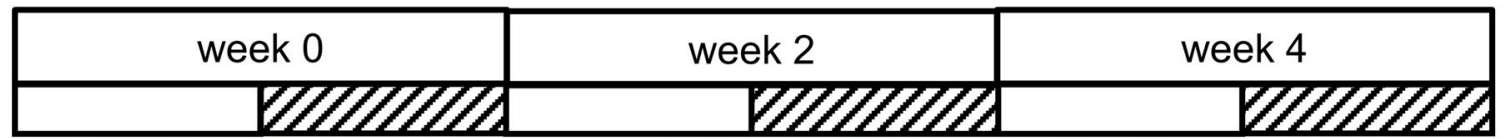

a

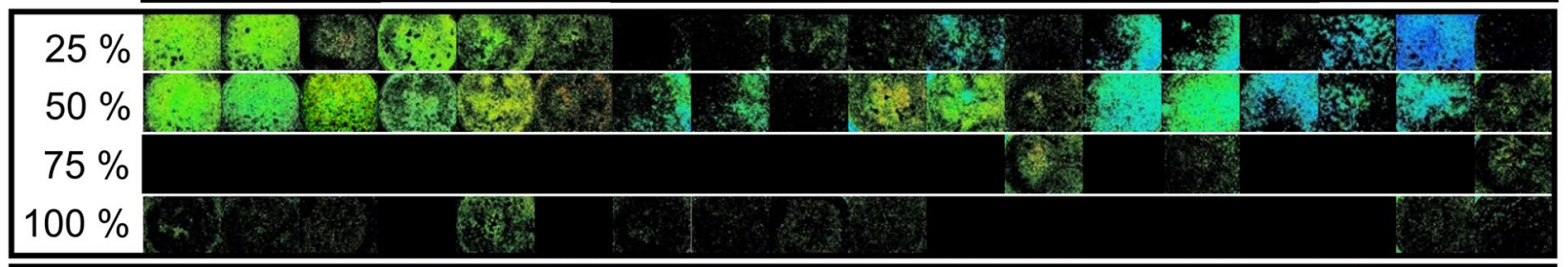

b

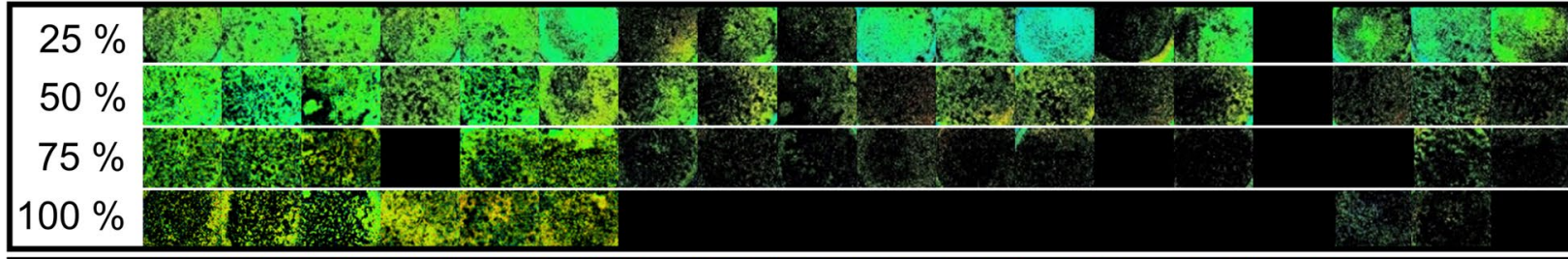

C

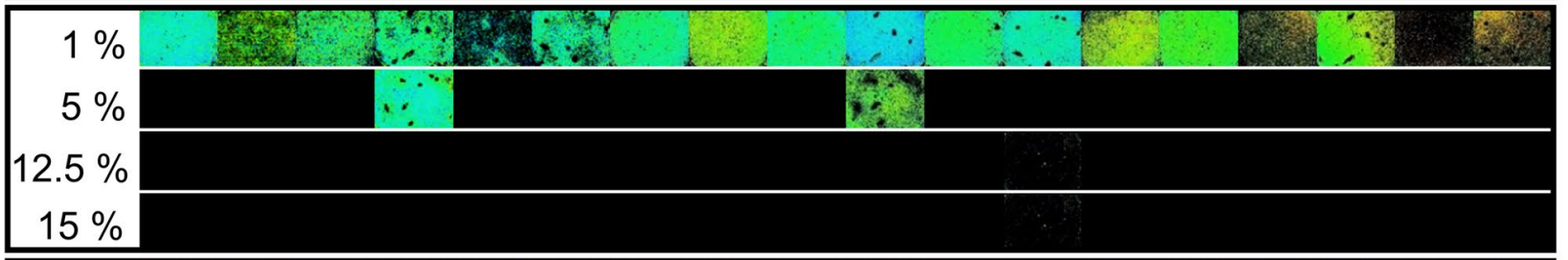

d

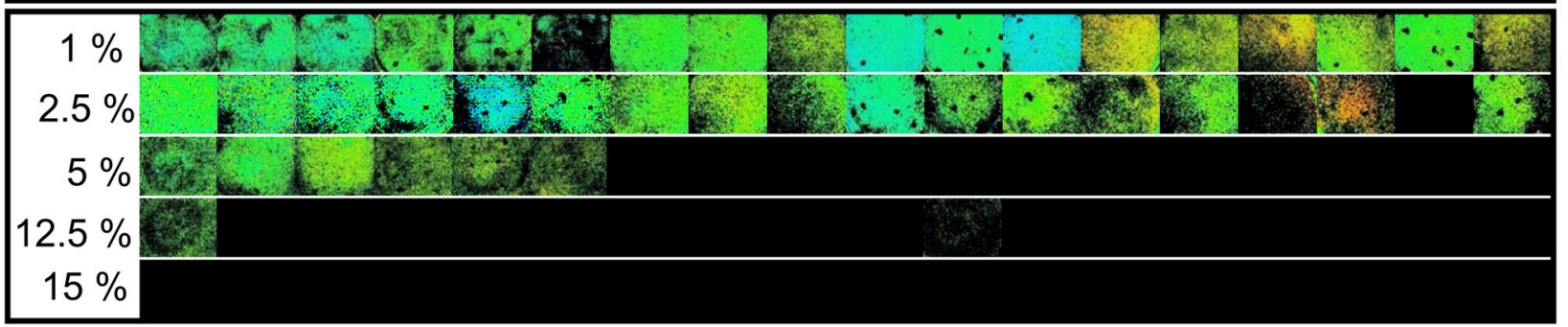

e

NoSalt
with additives

Fig. 3 Effective quantum yield $\mathrm{Y}$ (II) of the surface of saline substrates (a-d) as well as of a non-saline substrate (e) 0, 2, and 4 weeks after biocrust inoculation using a green algae mixture. Percentages refer to $(w / w)$ of the saline materials mixed with non-saline dune sand; a IHS (Infiltration Hampering Stratum); b NE (Neuhof-Ellers); c WS (waste salt); d NaCl; e NoSalt (100\% dune sand). Additives: $\mathrm{BC}^{\text {plus }}$ and sodium alginate 


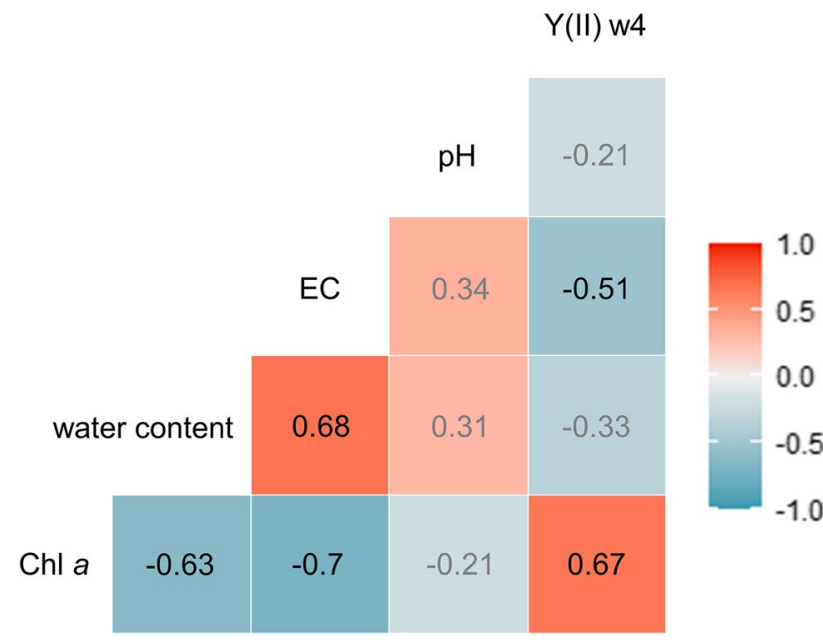

Fig. 4 Spearman's rank correlation test of properties determined in an experiment on artificial biocrust formation in a salinity gradient on materials from potash tailings piles. Y(II), Chl $a$, and water content were measured after 4 weeks, $\mathrm{EC}$ and $\mathrm{pH}$ indicate the initial substrate properties. Numbers refer to Spearman's correlation coefficient $(\rho)$

\section{Photosynthetic performance of the induced biocrusts}

The photosynthetic performance of the biocrusts changed over the course of the experiment (Fig. 3, Suppl. Figure 2). The I-PAM measurements directly after inoculation (Suppl. Figure 2a) showed the highest $Y($ II) in the NoSalt samples, which was on average 0.54 for NoSalt $\mathrm{A}^{-}$and 0.59 for NoSalt $\mathrm{A}^{+}$. Other samples exhibited no signal in either treatments $(75 \%(\mathrm{w} / \mathrm{w})$ IHS, $12.5 \%(\mathrm{w} / \mathrm{w}) \mathrm{WS}, 15 \%(\mathrm{w} / \mathrm{w})$ $\mathrm{NaCl}$ ). After 1 week (Suppl. Figure 2b), both treatments of $1 \%(\mathrm{w} / \mathrm{w}) \mathrm{NaCl}$ and $1 \%(\mathrm{w} / \mathrm{w})$ WS showed similar high Y(II) values as NoSalt, whereas those on all IHS substrates decreased compared to the previous week. The samples $100 \%(\mathrm{w} / \mathrm{w})$ IHS, $5 \%$ and $12.5 \%(\mathrm{w} / \mathrm{w}) \mathrm{NaCl}$ did not display a signal in addition to the inactive samples of the previous week. In the IHS samples, the measured Y(II) increased in the next 2 weeks, whereas in NoSalt, it decreased. After 4 weeks, one replicate of the $25 \%$ (w/w) IHS A ${ }^{+}$samples showed the highest photosynthetic performance (Fig. 3), whereas the mean Y(II) was particularly pronounced in both treatments of the $50 \%$ (w/w) IHS samples (Suppl. Figure 2e). There was a positive correlation between the Chl $a$ content and the Y(II) measured at week 4 (Fig. 4).

Furthermore, the 50\% (w/w) IHS samples with and without additives reached the highest increase from start to end of the experiment, calculated as the relative change of the effective quantum yield $\Delta \mathrm{Y}$ (II) after inoculation vs. end of the experiment (Fig. 5), i.e., photosynthetic performance in these IHS samples increased on average by $79 \%$ for $50 \%(\mathrm{w} / \mathrm{w})$ IHS $\mathrm{A}^{-}$and by $59 \%$ for $50 \%(\mathrm{w} / \mathrm{w})$ IHS $\mathrm{A}^{+}$, respectively. Both treatments of the $25 \%$ (w/w) IHS samples also exhibited an increase of the Y(II). Some replicates of these two substrates further reached a Y(II) that exceeded the value of week $0(\Delta \mathrm{Y}(\mathrm{II})>100 \%)$. In contrast, biocrusts on every other substrate did not reach a Y(II) that was higher than that after inoculation $(\Delta \mathrm{Y}(\mathrm{II})<0 \%)$.

\section{$\mathrm{Chl} a$ and water contents}

The Chl $a$ content was measured at the end of the experiment as a proxy for the biomass of the biocrusts (Fig. 6a). The Chl $a$ values were highest on $50 \%$ (w/w) IHS A- (mean $\left.40.33 \mathrm{mg} \mathrm{m}^{-2}\right)$ and $25 \%(\mathrm{w} / \mathrm{w})$ IHS A ${ }^{+}\left(22 \mathrm{mg} \mathrm{m}^{-2}\right)$, while $25 \%$ (w/w) $\mathrm{NE} \mathrm{A}^{+}, 1 \%$ (w/w) $\mathrm{WS} \mathrm{A}^{+}, 1 \%(\mathrm{w} / \mathrm{w}) \mathrm{NaCl} \mathrm{A}$, and NoSalt $\mathrm{A}^{+}$had values around $15 \mathrm{mg} \mathrm{m}^{-2}$. Among the treatments, the range of the $\mathrm{Chl} a$ content of the three replicates was larger by up to factor three, compared to the mean. The maximum range was observed in the $25 \%(\mathrm{w} / \mathrm{w})$ IHS $\mathrm{A}^{+}$sample (span $60.9 \mathrm{mg} \mathrm{m}^{-2}$ ); the three replicates showed a Chl $a$ content of $0 \mathrm{mg} \mathrm{m}^{-2}, 7.2 \mathrm{mg} \mathrm{m}^{-2}$, and $60.9 \mathrm{mg} \mathrm{m}^{-2}$, respectively. On other substrates, the range of the $\mathrm{Chl} a$ content was around 10 to $20 \mathrm{mg} \mathrm{m}^{-2}\left(15 \%(\mathrm{w} / \mathrm{w}) \mathrm{NE} \mathrm{A}^{+}, 1 \%\right.$ (w/w) $\mathrm{WS} \mathrm{A}^{+}, 1 \%(\mathrm{w} / \mathrm{w}) \mathrm{NaCl} \mathrm{A}+1 \%(\mathrm{w} / \mathrm{w}) \mathrm{NaCl} \mathrm{A}^{-}, 2.5 \%$ $\left.(\mathrm{w} / \mathrm{w}) \mathrm{NaCl} \mathrm{A}{ }^{+}\right)$.

The overall highest water content was in the IHS substrates (Fig. 6b). It increased gradually following the substrate concentrations, from a mean of $16 \%$ in the $25 \%(\mathrm{w} / \mathrm{w})$ IHS A ${ }^{-}$substrate to $29 \%$ in the $100 \%$ (w/w) IHS A ${ }^{+}$substrate. The same pattern was recorded in the NE substrates, but with about $30 \%$ lower values. Low water contents of about $5 \%(\mathrm{w} / \mathrm{w})$ were measured in $15 \%(\mathrm{w} / \mathrm{w}) \mathrm{WS} \mathrm{A}^{-}, 15 \%$ (w/w) $\mathrm{NaCl} \mathrm{A}{ }^{-}$, and $15 \%(\mathrm{w} / \mathrm{w}) \mathrm{WS} \mathrm{A}^{+}$. The NoSalt substrates had a mean water content of $8 \%(\mathrm{w} / \mathrm{w})$ in $\mathrm{A}^{-}$and $10 \%$ (w/w) in $\mathrm{A}^{+}$, respectively. Overall, Chl $a$ content values were negatively correlated with both $\mathrm{EC}$ and the water content (Fig. 4).

\section{Linking Chl $a$ content of the induced biocrust to the substrates EC}

The EC $\left(\mathrm{EC}_{\mathrm{BSC} \_ \text {growth }}\right)$ of samples with established biocrusts that showed higher Chl $a$ values at the end of the experiment compared to the inoculum ( $\left.\mathrm{Chl} a_{\text {End }}>\mathrm{Chl} a_{\text {Inoculum }}\right)$ was plotted in order to evaluate the EC limit for biocrust establishment (Fig. 7). The highest $\mathrm{EC}_{\mathrm{BSC} \_ \text {growth }}$ was measured in IHS $\mathrm{A}^{+}$and was $35.1 \mathrm{mS} \mathrm{cm}^{-1}$. In IHS A $\mathrm{A}^{-}$, the $\mathrm{EC}_{\mathrm{BSC}_{\text {_growth }} \text { was }}$ slightly lower but the respective biocrust samples showed higher Chl $a$ contents compared to IHS A $\mathrm{A}^{-}$. One replicate of WS $\mathrm{A}^{-}$had an increased $\mathrm{Chl} a$ content in conjunction with an EC of $34.3 \mathrm{mS} \mathrm{cm}^{-1}$. However, the respective $\mathrm{Chl}$ $a$ content was the lowest compared to the other established biocrust. All other biocrusts that established on WS showed a much lower $\mathrm{EC}_{\text {BSC_growth }}$ of $2.9-4.3 \mathrm{mS} \mathrm{cm}^{-1}$. The second 
Fig. 5 Relative change of the effective quantum yield $\mathrm{Y}$ (II) from week 0 to week 4 after biocrust inoculation on the surface of saline substrates as well as of a non-saline substrate. Percentages refer to $(\mathrm{w} / \mathrm{w})$ of the saline materials mixed with non-saline dune sand; IHS, Infiltration Hampering Stratum; NE, NeuhofEllers; WS, waste salt; NoSalt, non-saline dune sand. Each bar represents a mean value, with dots and asterisk representing single measurements of the three replicates. Positive values: increased Y(II); negative values: decreased $\mathrm{Y}(\mathrm{II}) ; \Delta \mathrm{Y}(\mathrm{II})=0$ : no change (e.g., no signals in both measurements); $\Delta \mathrm{Y}(\mathrm{II})=-100$ : signal in week 0 but no signal in week 4. Additives: $\mathrm{BC}^{\text {plus }}$ and sodium alginate

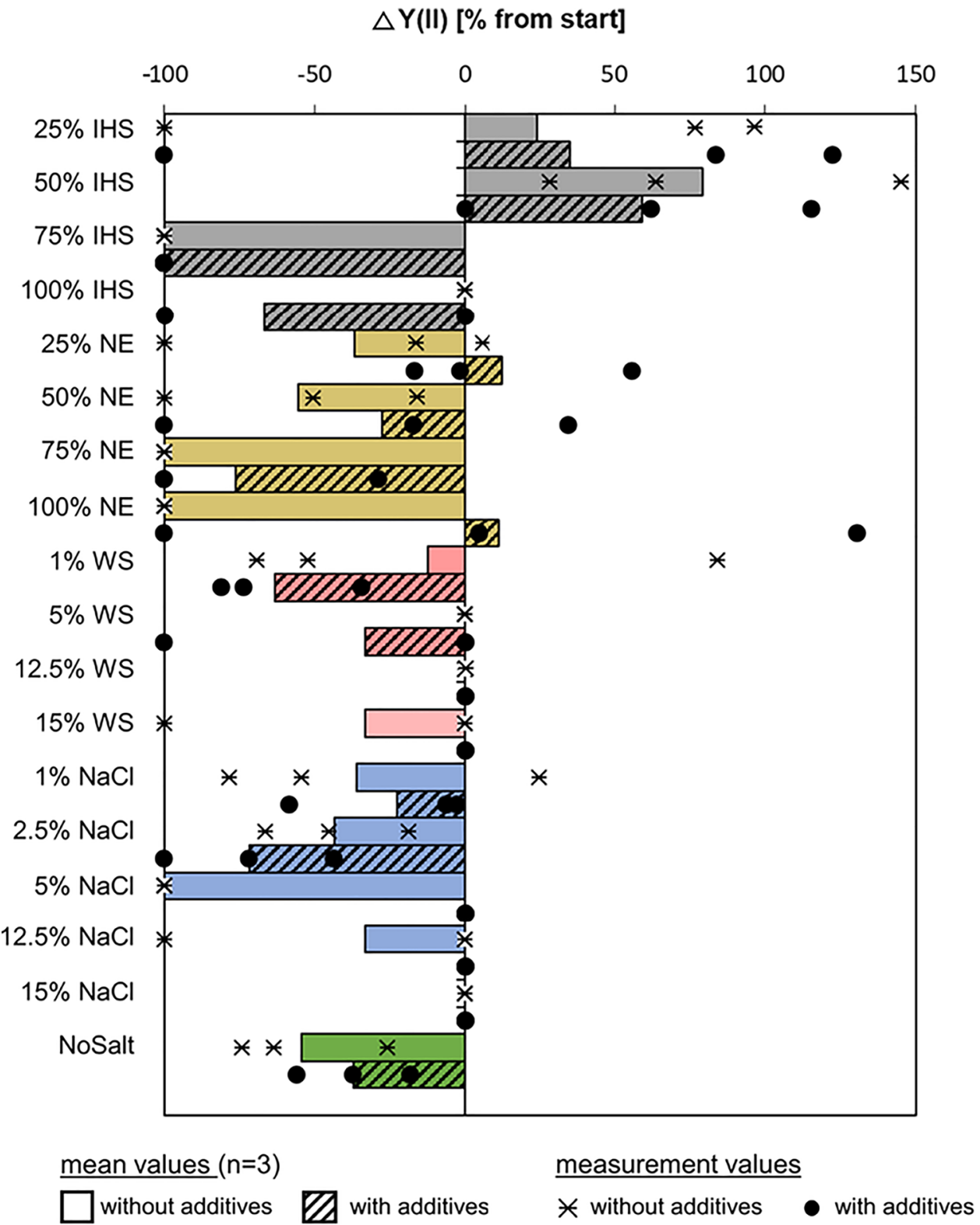

highest $\mathrm{EC}_{\mathrm{BSC} \_ \text {growth }}$ was also found in IHS substrates. The maximal $\mathrm{EC}_{\mathrm{BSC} \_ \text {growth }}$ of $\mathrm{NE}$ was $16.2 \mathrm{mS} \mathrm{cm}^{-1}$. All other biocrusts established on substrates with $\mathrm{EC}_{\mathrm{BSC}_{\text {_growth }}}<10$ $\mathrm{mS} \mathrm{cm}{ }^{-1}$. On substrates with an $\mathrm{EC}>35.1 \mathrm{mS} \mathrm{cm}^{-1}$, the $\mathrm{Chl}$ $a$ content after the experiment was always lower compared to the inoculum.

\section{Discussion}

\section{Biocrust establishment: assessing overall success}

The success of artificial biocrust establishment strongly depends on the inoculum (Román et al. 2018; Malešević et al. 2021) and can be determined by evaluating biocrust algal viability macroscopically, and under the microscope, as well as measuring Chl $a$ contents and photosynthetic performance. The visible green surfaces that partly or fully covered several substrates (Fig. 2) indicated successful biocrust establishment. The microscopic observation further detected vital microalgal communities strongly dominated by Pseudostichococcus monallantoides. The genus Pseudostichococcus occurs worldwide in a variety of habitats (Pröschold and Darienko 2020) and was frequently found in biocrusts in the surroundings of potash tailings piles (Sommer et al. 2020a, b). Therefore, it was used as the main green algal taxon of the inoculum mixture. In addition, Pseudostichococcus easily breaks into fragments, making fragmentation, which is, besides cell division, a common form of vegetative reproduction in this genus (Pröschold and Darienko 2020). 
Indeed, the homogenization of the microalgal mixture before inoculation may have led to increased fragmentation of the P. monallantoides filaments, thereby initiating fast growth when applied to the substrate. In contrast, the unicellular taxa Chloroidium sp. and Nannochloris sp. do not reproduce by fragmentation, and the homogenization process probably did not initiate autospore development. This may be the reason for the overall dominance of $P$. monallantoides in the established biocrusts after 4 weeks. On the other hand, the unicellular Chloroidium sp. and Nannochloris sp. may become important at a later stage of biocrust development, as they were commonly encountered in natural biocrusts growing near potash tailings piles (Sommer et al. 2020b).

The Chl $a$ content of several samples indicated increase of microalgal biomass, and thus successful biocrust establishment and growth (Fig. 6a). Overall, the highest mean $\mathrm{Chl} a$ content measured after the experiment (50\% (w/w) IHS A ${ }^{-}$) was 2.5 -fold lower than that of induced non-saline cyanobacteria biocrusts in a laboratory experiment under similar culturing conditions (Malešević et al. 2021). Salinity as an abiotic stressor is known to inhibit microalgal growth in liquid medium (Gustavs et al. 2010), suggesting slowed-down development of the inoculated microalgae on the saline substrates. However, the NoSalt samples did not exhibit significantly higher $\mathrm{Chl} a$ contents compared to the biocrusts that established on saline substrates. The study of Malešević et al. (2021) is based on cyanobacterial inoculation on a fertile loess surface, whereas the presented experiment used green algae on a less fertile substrate. Differences in mineral composition, nutrients, and physical structure may explain different biomass developments on these substrates. Studies on induced biocrusts using green algae are still lacking, although these eukaryotic microalgae often dominate biocrusts, particularly in mesic habitats (Glaser et al. 2018; Mikhailyuk et al. 2019). Natural green algal biocrusts on nutrient-depleted sandy soils showed $\mathrm{Chl}$ $a$ contents of $200-600 \mathrm{mg} \mathrm{m}^{-2}$ (Caesar et al. 2017), which is much higher compared to those in the experiment, but this may be explained by different age of the biocrusts, i.e., the biocrusts that established in the present study are very young and an early developmental stage. Nevertheless, the data of the present study document for the first time the successful application of green algae as an inoculum for the induction of biocrusts.

The cell numbers used for inoculation could be crucial for biomass development and biomass accumulation over time. For the inoculation using cyanobacteria, a dry weight of 5-7.5 $\mathrm{g} \mathrm{m}^{-2}$ led to successful biocrust establishment (Chamizo et al. 2018; Román et al. 2018; Roncero-Ramos et al. 2019; Mugnai et al. 2020). This is more than tenfold higher than the dry weight of the inoculum mixture used in this study. Furthermore, a thicker layer of inoculated organisms may have a positive influence on their survival on the saline substrates. The cells closest to the substrate could die off earlier, but still provide physical shelter from the direct influence of the salt for the organisms in upper layers of the crust. This could prolong their time for acclimation to the condition in the substrates. Therefore, a larger inoculated biomass may better support biocrust establishment on the substrates of potash tailings piles, which would lead to higher Chl $a$ contents after 4 weeks.

The highest measured Y(II) after the experiment reached comparable levels to that of natural cyanobacterial biocrusts under wet conditions (Williams et al. 2014) and was also comparable to those of green algae under standard culturing conditions (Schreiber et al. 2007). This indicates that the photosynthetic activity was on a high level reflecting healthy and unstressed green algae in the young biocrusts on the respective substrates, as well as a feasible methodological approach to follow artificial biocrusts development.

It is noteworthy that the $\mathrm{Chl} a$ content as well as the Y(II) showed a wide range of values for some substrates and treatments. While some replicates showed no biocrust development at all, biocrusts managed to establish on others. This suggests that the process of biocrust establishment is not homogenous, which should be considered in future experiments, for example, by optimizing the inoculation procedure and increasing the number of replicates.

\section{Biocrust establishment: evaluating the substrates and their EC}

The establishment of biocrusts differed between the substrates used in the experiment, revealing the crucial role of the substrate for artificial biocrust induction (Rozenstein et al. 2014; Román et al. 2018; Mugnai et al. 2020). Physico-chemical soil parameters shape the micro-habitat characteristics by providing both a physical matrix and a pool of beneficial, detrimental, and neutral chemical substances for the microorganisms. Water-holding capacities are further determined by the substrate. The highest $\mathrm{Chl} a$ content in combination with the highest increase of the photosynthetic performance was observed on the $50 \%(\mathrm{w} / \mathrm{w})$ IHS, followed by the $25 \%(w / w)$ IHS substrates. Consequently, biocrust establishment was most successful on the IHS. The fact that biocrusts naturally appeared on IHS surfaces in the field (Sommer et al. 2019) underlines the potential of biocrust establishment on this particular material.

The Chl $a$ content of the NoSalt samples was not the highest observed in this experiment, even though the collected salt-free dune sand is a habitat for natural biocrusts along the Baltic Sea coast (Schulz et al. 2016; Schaub et al. 2018; Khanipour Roshan et al. 2020). Likewise, the Y(II) of the NoSalt samples in both treatments decreased during the experiment, indicating a likely preference of the green 
a

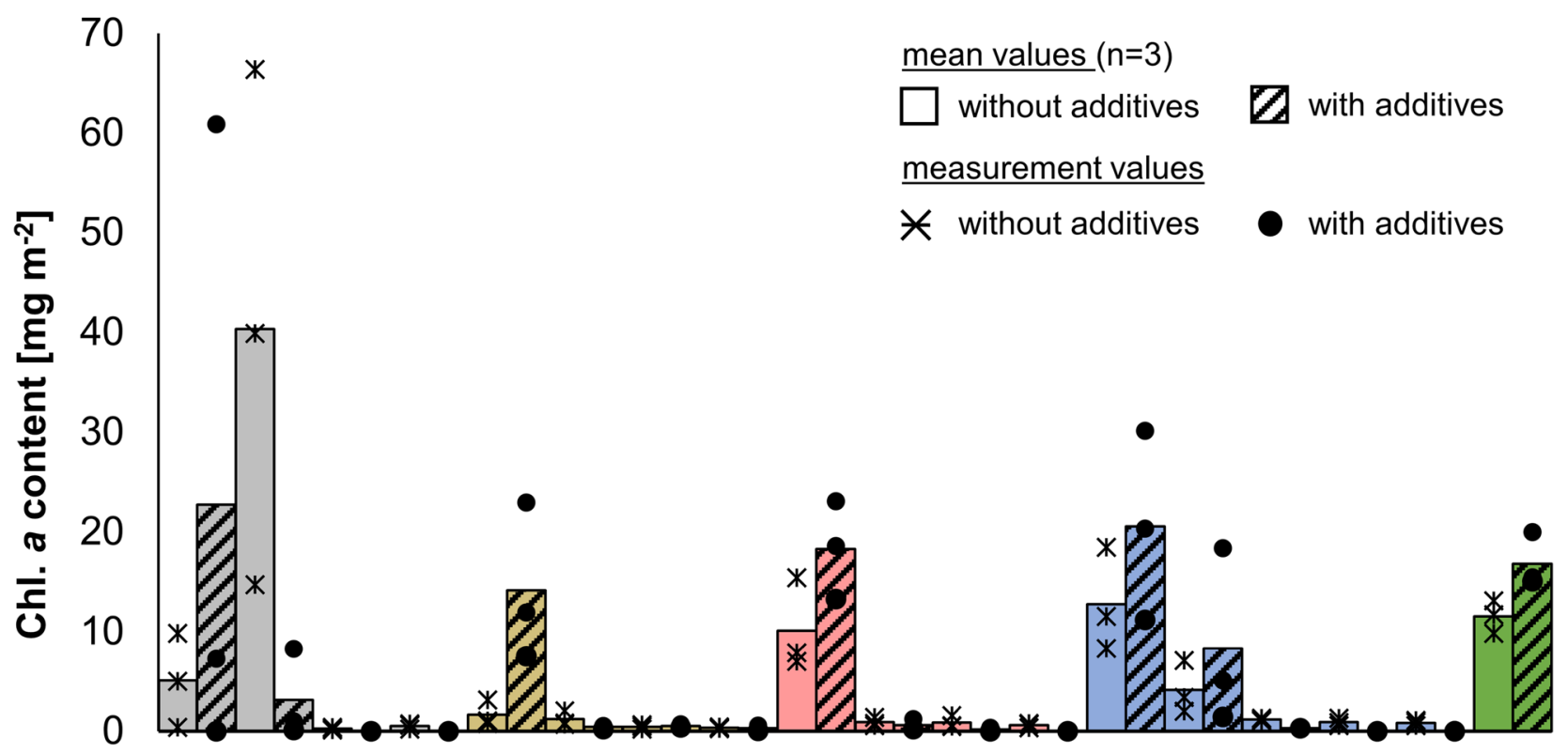

b

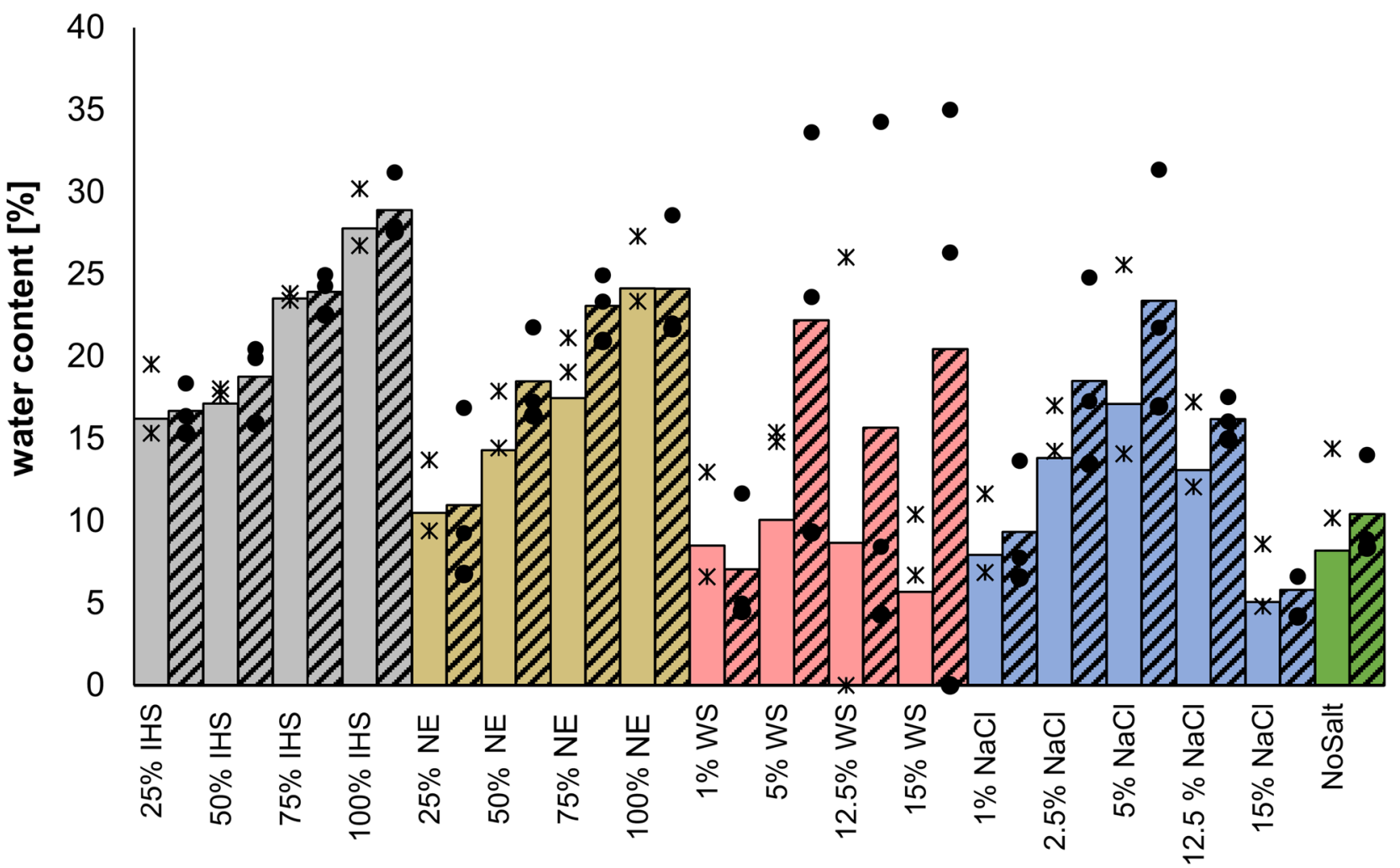

Fig. 6 Chlorophyll $a$ content of the surface (a) and water content of the sub-surface (b) 4 weeks after biocrust inoculation on saline substrates as well as of a non-saline substrate. Numbers refer to percentages $(w / w)$ of the saline material mixed with non-saline dune sand;

algae used for inoculation of saline over non-saline substrate. This is not surprising, since these algae were isolated from saline habitats. However, on the saline $1 \%(w / w) ~ N a C l$ and $1 \%(\mathrm{w} / \mathrm{w})$ WS substrates, the Y(II) similarly decreased
IHS, Infiltration Hampering Stratum; NE, Neuhof-Ellers; WS, waste salt; NoSalt, $100 \%$ non-saline dune sand. The bars represent mean values; values of each replicate are shown in addition. Additives: $\mathrm{BC}^{\text {plus }}$ and sodium alginate

during the experiment. These substrates mostly consisted of dune sand, and this material is not as hygroscopic as the more saline substrates. Gypsum, a component of the IHS (Kockx 2017), attracts water more easily than sand. Thus, 
Fig. 7 Electrical conductivities (ECs) of the substrates in all tested salinities that were suitable for biocrust induction. Dot positions represent the mean EC (of one substrate and treatment) referring to samples with successfully induced biocrusts showing increased biomass after the experiment $\left(\mathrm{Chl} a_{\text {End }}>\mathrm{Chl}\right.$ $\left.a_{\text {Inoculum }}\right)$. EC values of the substrates without biomass increase (Chl $\left.a_{\text {End }} \leq \mathrm{Chl} a_{\text {Inoculum }}\right)$ not shown. The dot size indicates the Chl $a_{\text {End }}$ of each sample. IHS, Infiltration Hampering Stratum; NE, Neuhof-Ellers; WS, waste salt; NoSalt, nonsaline dune sand. Additives: $\mathrm{BC}^{\text {plus }}$ and sodium alginate

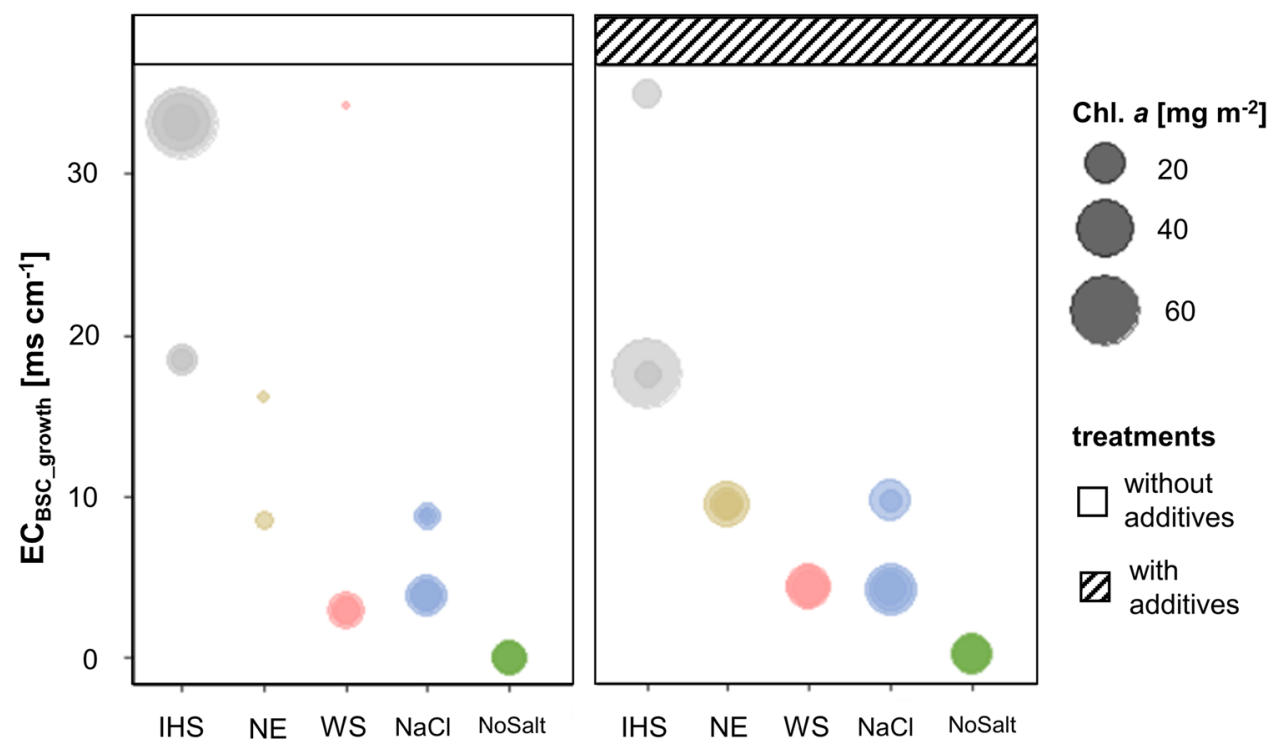

substrate the humidity on dune sand alone could have been insufficient to maintain an optimal water level for the biocrust algae. Indeed, the water content of the sub-crust of the NoSalt, as well as the $1 \%$ (w/w) $\mathrm{NaCl}$ and $1 \%$ (w/w) WS substrates, was about one-third lower compared to the samples with the highest Chl $a$ content (25\% (w/w) IHS A ${ }^{+}, 50 \%$ (w/w) IHS $\mathrm{A}^{-}$). This suggests that the photosynthetic performance of the biocrusts on dune sand declined due to drier conditions, which finally led to growth inhibition. Overall, these data are in congruence with a recent study that showed much lower cyanobacteria biocrust development in a dry chamber compared to in a wet chamber (Malešević et al. 2021).

Biocrusts did not establish on the $75 \%$ and $100 \%(\mathrm{w} / \mathrm{w})$ $\mathrm{NE}$ and IHS, nor on the $\mathrm{NaCl} / \mathrm{WS}$ substrates of $>5 \%$ (w/w). This correlated with the higher EC (as a proxy for soil salinity). Most of the samples showed photosynthetic activity after inoculation, whereas, for example, on $12.5 \%$ and $15 \%$ (w/w) WS, no chlorophyll fluorescence signal was detected. Thus, on most tested substrates, the algae survived the inoculation, except on strongly saline materials. The decreasing $\mathrm{Y}$ (II) values of some samples during the following weeks reflect the harmful effect of salt over a longer time period. The substrate salinity in these samples most probably exceeded the upper salt tolerance of the green algae, and consequently no biocrust could establish. An increased Y(II) at the end of the experiment in turn suggests that the salinities of the respective substrates were in a range compatible for survival. The critical salinity limit for biocrust establishment on potash tailings piles materials appears to be an $\mathrm{EC}_{\mathrm{BSC} \text { _growth }}$ of $35.1 \mathrm{mS} \mathrm{cm} \mathrm{cm}^{-1}$ (Fig. 7). This value resembles the maximum $\mathrm{EC}$ that was recorded in natural saline soil algal habitats (Tsujimura et al. 1998), whereas other studies on natural biocrust mostly reported much lower values in a range of $0-5 \mathrm{mS} \mathrm{cm} \mathrm{cm}^{-1}$ (Kakeh et al. 2018, 2020; Nyenda et al. 2019). However, the substrates $10 \%$ (w/w) WS, $10 \%$ (w/w) $\mathrm{NaCl}$, and $100 \%$ (w/w) NE also showed an EC of $30-45 \mathrm{mS} \mathrm{cm}^{-1}$, but no biocrusts developed. Therefore, factors other than the EC alone influence the development of biocrusts. The EC is a sum parameter and refers to the electrical conductivity in a medium provided by the dissolved ions. Typical salt ions are $\mathrm{Na}^{+}, \mathrm{K}^{+}$, and $\mathrm{Cl}^{-}$. The solubility of gypsum $\left(\mathrm{CaSO}_{4} 2 \mathrm{H}_{2} \mathrm{O}\right)$ is more than a hundred times lower than that of $\mathrm{NaCl}$, but $2.1 \mathrm{~g} \mathrm{~L}^{-1}$ dissolves in water (ions: $\mathrm{Ca}^{2+}, \mathrm{SO}_{4}{ }^{2-}$ ), thereby increasing the EC. Therefore, gypsum, as a main component of the IHS (Kockx 2017), could lead to an elevated EC in the IHS substrates of the present study. Interestingly, a study on Chlorella vulgaris showed an increase of the Chl $a$ content by adding gypsum to saline media, whereas the Chl $a$ content in saline media alone declined (Mathad and Hiremath 2010). This might be explained by the beneficial role of $\mathrm{Ca}^{2+}$ for algae, for example, as a secondary messenger in calcium-signaling pathways. The gypsum as a component of the IHS may further protect the algal cells from more toxic salt ions, such as $\mathrm{Na}^{+}$ and $\mathrm{Cl}^{-}$, and thereby allowing the biocrust establishment on substrates with a higher EC.

Soil texture is another factor influencing artificial biocrust development. Cyanobacterial biocrust establishment on fine sand was more successful than on coarse sand (Rozenstein et al. 2014; Mugnai et al. 2020). In contrast, the Chl $a$ content of cyanobacterial biocrusts after 30 days was lower on silt loam to loamy sand than on sandy sand; however, biocrusts on sandy sand were more fragile (Chamizo et al. 2018). The additives as a component of the IHS belong to the soil texture "silt" (0.002 to $0.05 \mathrm{~mm}$ particle diameter; Kockx 2017), whereas dune sand from the Baltic Sea coast 
has been classified as "sandy sand" ( 0.05 to $2.0 \mathrm{~mm}$ particle diameter; Schulz et al. 2016). As the silt fraction of the IHS substrates provided a larger reactive surface than the coarsetextured dune sand, this addition of finer particles may have provided reactive surface and nutrient reservoirs supporting the biocrust establishment.

Moreover, mixing the potash tailings piles materials IHS and NE with dune sand aimed to simulate natural weathering processes. Under outdoor conditions, rain dissolves the soluble components of the tailings (mostly $\mathrm{NaCl}$ ) that will then be washed out, whereas the insoluble components remain on the surface, leading to a desalinization of the surface layer. The insoluble and hardly soluble components in the IHS derive from the IHS-additives, as well as from the 1-2\% insoluble and hardly soluble components of the overburden (gypsum/anhydrite, clay; Kockx 2017). After 4 years in an outdoor pilot study, the IHS showed a layer thickness of 3-9.4 cm and a mean $\mathrm{NaCl}$ content of 25\% (Kockx 2017), suggesting that the salinity declines with time. Consequently, more time may be required to further reduce the salinity of the IHS, in order to allow biocrust establishment on the IHS in the field.

\section{Biocrust establishment: evaluating the treatment}

The application of sodium alginate as a surface stabilizer in combination with $\mathrm{BC}^{\text {plus }}$ as a nutrient source significantly increased the biocrusts $\mathrm{Chl} a$ content on the NE, WS, $\mathrm{NaCl}$, and NoSalt substrates (Table 3). Therefore, we confirm statements on beneficial effects of surface stabilizers on artificial biocrust formation (Peng et al. 2017; Chi et al. 2020). Sodium alginate increases the compressive strength of the soil by forming a film on the surface, which supported the induction of cyanobacterial biocrusts on sand (Peng et al. 2017). Our results showed that green algae likewise benefit from this stabilizer. The stabilizing effect could be even more important for single-celled green algae (Chloroidium sp., Nannochloris sp.) as well as the easily fragmenting filaments of $P$. monallantoides compared to the robust, EPS-excreting filamentous cyanobacterium Microcoleus vaginatus used by Peng et al. (2017). Furthermore, the water content of biocrusts with sodium alginate application was higher compared to the control (Peng et al. 2017), which is in accordance with our results. It is thus reasonable to assume that a higher water availability could have supported biocrust establishment on the respective substrates.

The increased Chl $a$ content on several substrates with the additive treatment furthermore suggests a promotion of the biocrust growth by the second additive, $\mathrm{BC}^{\text {plus }}$. This can be explained by the release of additional nutrients like phosphate, sulfate, $\mathrm{Ca}^{2+}$, and $\mathrm{Mg}^{2+}$ from $\mathrm{BC}^{\text {plus }}$, corresponding to positive crop yield effects of $\mathrm{BC}^{\text {plus }}$ application in agronomic experiments (Zimmer et al. 2019). Also, $\mathrm{BC}^{\text {plus }}(\mathrm{pH}$ 5) application can decrease the soil $\mathrm{pH}$ (Zimmer et al. 2019). Indeed, the $\mathrm{BC}^{\text {plus }}$ treatments showed a lower $\mathrm{pH}$ than the samples without treatment (Table 3). This is an advantage in sodic substrates, since nutrient availability strongly depends on soil $\mathrm{pH}$. The availability of phosphorous and trace metals strongly decreases at $\mathrm{pH}>7.5$, as it was the case for most of the substrates used in this study (Table 3). Future studies could further evaluate the nutrient availability in potash tailings piles substrates enriched with $\mathrm{BC}^{\text {plus }}$.

Since the additive treatment generally enhanced biocrust establishment on substrates of moderately high salinity, sodium alginate and $\mathrm{BC}^{\text {plus }}$ are beneficial for the development of biocrusts. However, both additives did not enhance the salinity tolerance of the inoculated microalgae. Determining the optimal additive concentration under controlled laboratory conditions is another crucial step for the application in future outdoor experiments. Sodium alginate was applied in a concentration that has been shown to be effective before (Peng et al. 2017), although some modifications of the protocol may be useful because of the specific EC, $\mathrm{pH}$, and soil texture conditions of the materials from the potash tailings piles.

\section{Conclusion}

In this pioneer study, green algae were for the first time successfully applied to the artificial induction of biocrusts on saline substrates containing potash tailings pile materials in the laboratory. Pseudostichococcus monallantoides was the dominant alga in the established biocrusts and thus represents a suitable halotolerant green algal inoculum for restoration purposes. However, many other green algal strains, several of them belonging to undescribed taxa, have been reported from these biocrusts (Sommer et al. 2020a, b), and the potential to identify strains that could be even more salt-tolerant has so far not been systematically investigated. Moreover, several cyanobacterial isolates were obtained from biocrusts growing in the vicinity of potash tailings piles surroundings (Sommer et al. 2020b). These strains should be also tested for the restoration of potash tailings piles, since inoculation of filamentous cyanobacteria led to successfully established biocrusts in several studies (Rossi et al. 2017; Román et al. 2018; Malešević et al. 2021; Zhao et al. 2021). The focus of the present study, however, was set to green microalgae, since this group was more prominent in young biocrusts collected from the closest potash tailings piles environments (Sommer et al. 2020a) and on the IHS in the field (Sommer et al. 2019). In addition, green algae are more abundant in temperate biocrusts compared to drylands, 
where cyanobacteria are more important (Glaser et al. 2018).

The establishment of biocrusts was most successful on the potash tailings piles material IHS that was mixed with dune sand at proportions of $25 \%(\mathrm{w} / \mathrm{w})$ IHS and $50 \%$ (w/w) IHS, resulting in an EC $<35 \mathrm{mS} \mathrm{cm}$, whereas substrates with a higher EC were not suitable for biocrust establishment. These findings provide a first baseline on the physico-chemical conditions required for biocrust establishment on potash tailings piles. The biocrust establishment on the IHS on potash tailings piles materials possibly bears the potential to improve water retention that may in consequence lower the harmful salt output after precipitation events. Eventually, a living biocrust cover, which provided beneficial effects like surface stabilization, nutrient accumulation, and water retention, may be the first step towards a renaturalization of potash tailings piles.

Supplementary Information The online version contains supplementary material available at https://doi.org/10.1007/s10811-021-02609-7.

Acknowledgements The authors acknowledge the funding of the Deutsche Bundesstiftung Umwelt (Az. 20016/462), DECHEMA Gesellschaft für Chemische Technik und Biotechnologie e.V. (MBFSt 3583), and $\mathrm{K}+\mathrm{S}$ Minerals and Agriculture $\mathrm{GmbH}$.

Author contribution Conceptualization: V. Sommer, K. Glaser, and A. Schink; methodology: V. Sommer, A. Schink; formal analysis and investigation: V. Sommer, K. Glaser; writing—original draft preparation: V. Sommer; writing-review and editing: P. Leinweber, A. Palm, U. Karsten, K. Glaser, A. Palm, N. Gose; funding acquisition: V. Sommer, A. Palm, K. Glaser; supervision: U. Karsten.

Funding Open Access funding enabled and organized by Projekt DEAL. The study was funded by a scholarship of the Deutsche Bundesstiftung Umwelt (Az. 20016/462) to V. Sommer, a Max-Buchner-Forschungsstipendium (DECHEMA; MBFSt 3583) to K. Glaser, and by funding from $\mathrm{K}+\mathrm{S}$ Minerals and Agriculture $\mathrm{GmbH}$ to A. Palm and N. Gose.

Data availability All data is provided in the article.

\section{Declarations}

Conflict of interest The authors declare no competing interests.

Open Access This article is licensed under a Creative Commons Attribution 4.0 International License, which permits use, sharing, adaptation, distribution and reproduction in any medium or format, as long as you give appropriate credit to the original author(s) and the source, provide a link to the Creative Commons licence, and indicate if changes were made. The images or other third party material in this article are included in the article's Creative Commons licence, unless indicated otherwise in a credit line to the material. If material is not included in the article's Creative Commons licence and your intended use is not permitted by statutory regulation or exceeds the permitted use, you will need to obtain permission directly from the copyright holder. To view a copy of this licence, visit http://creativecommons. org/licenses/by/4.0/.

\section{References}

Ballesteros M, Ayerbe J, Casares M, Cañadas EM, Lorite J (2017) Successful lichen translocation on disturbed gypsum areas: a test with adhesives to promote the recovery of biological soil crusts. Sci Rep 7:1-9

Barger NN, Weber B, Garcia-Pichel F, Zaady E, Belnap J (2016) Patterns and controls on nitrogen cycling of biological soil crusts. In: Weber B, Büdel B, Belnap J (eds) Biological soil crusts: an organizing principle in drylands. Springer, Cham, pp 257-285

Baumann K, Glaser K, Mutz JE, Karsten U, MacLennan A, Hu Y, Michalik D, Kruse J, Eckhardt K-U, Schall P, Leinweber P (2017) Biological soil crusts of temperate forests: their role in P cycling. Soil Biol Biochem 109:156-166

Belnap J (2006) The potential roles of biological soil crusts in dryland hydrologic cycles. Hydrol Process 20:3159-3178

Belnap J, Büdel B (2016) Biological soil crusts as soil stabilizers. In: Weber B, Büdel B, Belnap J (eds) Biological soil crusts: an organizing principle in drylands. Springer, Cham, pp 305-320

Belnap J, Eldridge DJ (2003) Disturbance and recovery of biological soil crusts. In: Belnap J, Lange OL (eds) Biological soil crusts: structure, function, and management. Springer, Berlin, pp 364-383

Bischoff HW, Bold HC (1963) Some soil algae from enchanted rock and related algal species. In: phycological studies IV. University of Texas Publication No. 6318. Austin, Texas, pp 1-95

Bowker MA, Eldridge DJ, Val J, Soliveres S (2013) Hydrology in a patterned landscape is co-engineered by soil-disturbing animals and biological crusts. Soil Biol Biochem 61:14-22

Breen K, Lévesque E (2006) Proglacial succession of biological soil crusts and vascular plants: biotic interactions in the High Arctic. Can J Bot 84:1714-1731

Bu C, Li R, Wang C, Bowker MA (2018) Successful field cultivation of moss biocrusts on disturbed soil surfaces in the short term. Plant Soil 429:227-240

Burgstaller J, Wiedow D, Leinweber P (2012) Verfahren zur Reinigung von Gasen oder Flüssigkeiten, Adsorbens dafür, Filter, sowie Verwendung des Adsorptionsmittels. PCT Patent Application WO 2012/107022

Caesar J, Tamm A, Ruckteschler N, Weber B (2017) Revisiting chlorophyll extraction methods in biological soil crusts-methodology for determination of chlorophyll $a$ and chlorophyll $a+b$ as compared to previous methods. Biogeosciences 15:1415-1424

Chamizo S, Cantón Y, Rodríguez-Caballero E, Domingo F (2016) Biocrusts positively affect the soil water balance in semiarid ecosystems. Ecohydrology 9:1208-1221

Chamizo S, Mugnai G, Rossi F, Certini G, De Philippis R (2018) Cyanobacteria inoculation improves soil stability and fertility on different textured soils: gaining insights for applicability in soil restoration. Front Environ Sci 6:49

Chen L, Xie Z, Hu C, Li D, Wang G, Liu Y (2006) Man-made desert algal crusts as affected by environmental factors in Inner Mongolia, China. J Arid Environ 67:521-527

Chi Y, Li Z, Zhang G, Zhao L, Gao Y, Wang D, Liu L, Cai D, Wu Z (2020) Inhibiting desertification using aquatic cyanobacteria assisted by a nanocomposite. ACS Sustain Chem Eng 8:3477-3486

Condon LA, Pietrasiak N, Rosentreter R, Pyke DA (2020) Passive restoration of vegetation and biological soil crusts following 80 years of exclusion from grazing across the Great Basin. Restor Ecol 28:S75-S85

Cruz de Carvalho R, dos Santos P, Branquinho C (2018) Production of moss-dominated biocrusts to enhance the stability and function of the margins of artificial water bodies. Restor Ecol 26:419-421 
Elbert W, Weber B, Burrows S, Steinkamp J, Büdel B, Andreae MO, Poschl U (2012) Contribution of cryptogamic covers to the global cycles of carbon and nitrogen. Nat Geosci. https:// doi.org/10.1038/NGEO1486

Erdmann N, Hagemann M (2001) Salt acclimation of algae and cyanobacteria: a comparison. In: Rai LC, Gaur JP (eds) Algal adaptation to environmental stresses. Springer, Berlin, pp 323-361

Fattahi SM, Soroush A, Huang N (2020) Wind erosion control using inoculation of aeolian sand with cyanobacteria. Land Degrad Develop 31:2104-2116

Glaser K, Baumann K, Leinweber P, Mikhailyuk T, Karsten U (2018) Algal richness in BSCs in forests under different management intensity with some implications for $\mathrm{P}$ cycling. Biogeosciences 15:4181-4192

Gustavs L, Eggert A, Michalik D, Karsten U (2010) Physiological and biochemical responses of green microalgae from different habitats to osmotic and matric stress. Protoplasma 243:3-14

Gustavs L, Görs M, Karsten U (2011) Polyol patterns in biofilmforming aeroterrestrial green algae (Trebouxiophyceae, Chlorophyta). J Phycol 47:533-537

Gypser S, Veste M, Fischer T, Lange P (2016) Infiltration and water retention of biological soil crusts on reclaimed soils of former open-cast lignite mining sites in Brandenburg, north-east Germany. J Hydrol Hydromech 64:1-11

HELCOM (2015) Annex C-4. Phytoplankton chlorophyll a. In: Manual for marine monitoring in the COMBINE program of HELCOM. HELCOM, Helsinki, pp 257-263

Kakeh J, Gorji M, Sohrabi M, Tavili A, Pourbabaee AA (2018) Effects of biological soil crusts on some physicochemical characteristics of rangeland soils of Alagol, Turkmen Sahra, NE Iran. Soil Tillage Res 181:152-159

Kakeh J, Gorji M, Mohammadi MH, Asadi H, Khormali F, Sohrabi M, Cerdà A (2020) Biological soil crusts determine soil properties and salt dynamics under arid climatic condition in Qara Qir, Iran. Sci Total Environ 732:139168

Khanipour Roshan S, Dumack K, Bonkowski M, Karsten U, Glaser K (2020) Stramenopiles and Cercozoa dominate the heterotrophic protist community of biological soil crusts irrespective of edaphic factors. Pedobiologia (jena) 83:150673

Kidron GJ (2016) Linking surface and subsurface properties of biocrusted and non-biocrusted habitats of fine-grained fluvial sediments (playas) from the Negev Desert. J Hydrol Hydromechanics 64:141-149

Kidron GJ (2019) Biocrust research: a critical view on eight common hydrological-related paradigms and dubious theses. Ecohydrology 12:e2061

Kockx M (2017) Die Infiltrationshemmschicht als Oberflächenabdeckung für Rückstandshalden der Kaliindustrie. Dissertation, Technische Universität Clausthal

Li Z, Chen C, Gao Y et al (2021) Synergistic effect of cyanobacteria and nano-sand-stabilizer on biocrust formation and sand fixation. J Environ Chem Eng 9:104887

Malešević TP, Dulić T, Obreht I, Trivunović Z, Marković R, Kostić B, Važić T, Meriluoto J, Svirčev Z (2021) Cyanobacterial potential for restoration of loess surfaces through artificially induced biocrusts. Appl Sci 11:66

Mathad P, Hiremath S (2010) Alleviation of saline stress by gypsum in Chlorella vulgaris BEIJERINCK. J Algal Biomass Util 1:43-53

Mikhailyuk T, Glaser K, Tsarenko P, Demchenko E, Karsten U (2019) Composition of biological soil crusts from sand dunes of the Baltic Sea coast in the context of an integrative approach to the taxonomy of microalgae and cyanobacteria. Eur J Phycol 54:263-290

Mugnai G, Rossi F, Chamizo S, Adessi A, De Philippis R (2020) The role of grain size and inoculum amount on biocrust formation by Leptolyngbya ohadii. CATENA 184:104248
Niessing S (2005) Begrünungsmaßnahmen auf der Rückstandshalde des Kaliwerkes Sigmundshall in Bokeloh. Universität Kassel, Kassel

Nyenda T, Jacobs SM, Gwenzi W, Muvengwi J (2019) Biological crusts enhance fertility and texture of gold mine tailings. Ecol Eng 135:54-60

Park C-H, Li X-R, Jia R-L, Hur J-S (2017) Combined application of cyanobacteria with soil fixing chemicals for rapid induction of biological soil crust formation. Arid Land Res Manag 31:81-93

Peng C, Zheng J, Huang S, Li S, Li D, Cheng M, Liu Y (2017) Application of sodium alginate in induced biological soil crusts: enhancing the sand stabilization in the early stage. J Appl Phycol 29:1421-1428

Pröschold T, Darienko T (2020) The green puzzle Stichococcus (Trebouxiophyceae, Chlorophyta): new generic and species concept among this widely distributed genus. Phytotaxa 441:113-142

Ritchie RJ (2008) Universal chlorophyll equations for estimating chlorophylls $a, b, c$, and $d$ and total chlorophylls in natural assemblages of photosynthetic organisms using acetone, methanol, or ethanol solvents. Photosynthetica 46:115-126

Rodríguez-Caballero E, Chamizo S, Roncero-Ramos B, Roman R, Canton Y (2018) Runoff from biocrust: a vital resource for vegetation performance on Mediterranean steppes. Ecohydrology 11:e1977

Román JR, Roncero-Ramos B, Chamizo S, Rodríguez-Caballero E, Cantón Y (2018) Restoring soil functions by means of cyanobacteria inoculation: importance of soil conditions and species selection. Land Degrad Dev 29:3184-3193

Roncero-Ramos B, Román JR, Gómez-Serrano CG, Cantón Y, Acién FG (2019) Production of a biocrust-cyanobacteria strain (Nostoc commune) for large-scale restoration of dryland soils. J Appl Phycol 31:2217-2230

Rossi F, Li H, Liu Y, De Philippis R (2017) Cyanobacterial inoculation (cyanobacterisation): perspectives for the development of a standardized multifunctional technology for soil fertilization and desertification reversal. Earth-Sci Rev 171:28-43

Rozenstein O, Zaady E, Katra I, Karnieli A, Adamowski J, Yizhaq H (2014) The effect of sand grain size on the development of cyanobacterial biocrusts. Aeolian Res 15:217-226

Sancho LG, Belnap J, Colesie C, Raggio J, Weber B (2017) Carbon budgets of biological soil crusts at micro-, meso-, and global scales. In: Weber B, Büdel B, Belnap J (eds) Biological soil crusts: an organizing principle in drylands. Springer, Cham, pp 287-304

Schaub I, Baum C, Schumann R, Karsten U (2018) Effects of an early successional biological soil crust from a temperate coastal sand dune (NE Germany) on soil elemental stoichiometry and phosphatase activity. Microb Ecol 77:217-229

Schmeisky H, Podlacha G (2000) Natural revegetation of saline waste dumps-drought tolerant specialists and halophytes. Landsc Urban Plan 51:159-163

Schreiber U, Quayle P, Schmidt S, Escher BI, Mueller J (2007) Methodology and evaluation of a highly sensitive algae toxicity test based on multiwell chlorophyll fluorescence imaging. Biosens Bioelectron 22:2554-2563

Schulz K, Mikhailyuk T, Dreßler M, Leinweber P, Karsten U (2016) Biological soil crusts from coastal dunes at the Baltic Sea: cyanobacterial and algal biodiversity and related soil properties. Microb Ecol 71:178-193

Siebers N, Leinweber P (2009) Bone char: a clean and renewable phosphorus fertilizer with cadmium immobilization capability. J Environ Qual 42:405-411

Sommer V, Kockx M, Wölk A, Glaser K (2019) Von Vogelkot zu grünen Teppichen. Biol Unserer Zeit 49:122-130 
Sommer V, Karsten U, Glaser K (2020a) Halophilic algal communities in biological soil crusts isolated from potash tailings pile areas. Front Ecol Evol 8:46

Sommer V, Mikhailyuk T, Glaser K, Karsten U (2020b) Uncovering unique green algae and cyanobacteria isolated from biocrusts in highly saline potash tailing pile habitats, using an integrative approach. Microorganisms 8:1667

Starr RC, Zeiskus JA (1993) UTEX - the culture collection of algae at the University of Texas at Austin. J Phycol Suppl 29:1-106

Tsujimura S, Tsujimura S, Nakahara H, Kosaki T, Ishida N, Karbozova E (1998) Distribution of soil algae in salinized irrigation land in the arid region of Central Asia: II. A case study of 25-year-old bakbakty farm in the flood plain of the river Ili, Kazakstan. Soil Sci Plant Nutr 44:67-76

Weber B, Bowker M, Zhang Y, Belnap J (2016a) Natural recovery of biological soil crusts after disturbance. In: Weber B, Büdel B, Belnap J (eds) Biological soil crusts: an organizing principle in drylands. Springer, Cham, pp 479-498

Weber B, Büdel B, Belnap J (eds) (2016b) Biological soil crusts: an organizing principle in drylands. Springer, Cham

Whitney KM, Vivoni ER, Duniway MC, Bradford JB, Reed SC, Belnap J (2017) Ecohydrological role of biological soil crusts across a gradient in levels of development. Ecohydrology 10:e1875

Williams AP, Avery LM, Killham K, Jones DL (2005) Persistence of Escherichia coli $\mathrm{O} 157$ on farm surfaces under different environmental conditions. J Appl Microbiol 98:1075-1083
Williams WJ, Büdel B, Reichenberger H, Rose N (2014) Cyanobacteria in the Australian northern savannah detect the difference between intermittent dry season and wet season rain. Biodivers Conserv 23:1827-1844

Williams W, Schneemilch M, Chilton A, Schneemilch M, Williams S, Neilan B, Driscoll C (2019) Microbial biobanking cyanobacteria-rich topsoil facilitates mine rehabilitation. Biogeosciences 16:2189-2204

Xiao B, Zhao Y, Wang Q, Li C (2015) Development of artificial mossdominated biological soil crusts and their effects on runoff and soil water content in a semi-arid environment. J Arid Environ 117:75-83

Yang X, Xu M, Zhao Y, Bao T, Ren W, Shi Y (2020) Trampling disturbance of biocrust enhances soil carbon emission. Rangel Ecol Manag 73:501-510

Zaady E, Arbel S, Barkai D, Sarig S (2013) Long-term impact of agricultural practices on biological soil crusts and their hydrological processes in a semiarid landscape. J Arid Environ 90:5-11

Zhao Y, Wang N, Zhang Z, Pan Y, Jia R (2021) Accelerating the development of artificial biocrusts using covers for restoration of degraded land in dryland ecosystems. Land Degrad Dev 32:285-295

Zimmer D, Panten K, Frank M, Springer A, Leinweber P (2019) Sulfurenriched bone char as alternative $\mathrm{P}$ fertilizer: spectroscopic, wet chemical, and yield response evaluation. Agriculture 9:21

Publisher's note Springer Nature remains neutral with regard to jurisdictional claims in published maps and institutional affiliations. 